



\section{Verkenning gevolgen GLB-voorstellen voor landbouwinkomens in Nederland}

Ida Terluin, Petra Berkhout, Jakob Jager en Harold van der Meulen 
Terluin, Ida J.; Petra Berkhout; Jakob Jager, Harold van der Meulen, 2018. Verkenning gevolgen GLBvoorstellen voor landbouwinkomens in Nederland; . Wageningen, Wageningen Economic Research, Rapport 2018-084. 42 blz.;16 tab.; 8 ref.

De wetgevende voorstellen voor het Gemeenschappelijk Landbouwbeleid (GLB) voor de periode 20212027 geven lidstaten veel vrijheid in de toekenning van de toeslagen uit de eerste pijler. De gevolgen van de voorgenomen herziening van het GLB voor het inkomen van de land- en tuinbouwbedrijven zijn sterk afhankelijk van de keuzes die door Nederland worden gemaakt in deze toekenning. Deze gevolgen kunnen beperkt zijn, of juist heel groot. De studie geeft inzicht in welke keuzes leiden tot welke gevolgen, aan de hand van vijf mogelijke scenario's voor de invulling van de eerste pijler van het GLB voor de periode 2021-2027.

The legislative proposals for the Common Agricultural Policy (CAP) for the 2021-2027 period give Member States a great deal of freedom in granting payments from the first pillar. The impact of the planned revision of the CAP on the income of agricultural and horticultural organisations depends to a large extent on the choices made by the Netherlands in granting these payments. These consequences will be either limited or very significant. The study provides insight into which choices lead to which consequences based on five possible scenarios for the implementation of the first pillar of the CAP for the 2021-2027 period.

Trefwoorden: hervorming, GLB, inkomen, land- en tuinbouw

Dit rapport is gratis te downloaden op https://doi.org/10.18174/460150 of op www.wur. nl/economicresearch (onder Wageningen Economic Research publicaties).

(C) 2018 Wageningen Economic Research

Postbus 29703, 2502 LS Den Haag, T 07033583 30, E communications.ssg@wur.nl, www.wur.nl/economic-research. Wageningen Economic Research is onderdeel van Wageningen University \& Research.

\section{(cc) BY-NC}

Wageningen Economic Research hanteert voor haar rapporten een Creative Commons Naamsvermelding 3.0 Nederland licentie.

(C) Wageningen Economic Research, onderdeel van Stichting Wageningen Research, 2018 De gebruiker mag het werk kopiëren, verspreiden en doorgeven en afgeleide werken maken. Materiaal van derden waarvan in het werk gebruik is gemaakt en waarop intellectuele eigendomsrechten berusten, mogen niet zonder voorafgaande toestemming van derden gebruikt worden. De gebruiker dient bij het werk de door de maker of de licentiegever aangegeven naam te vermelden, maar niet zodanig dat de indruk gewekt wordt dat zij daarmee instemmen met het werk van de gebruiker of het gebruik van het werk. De gebruiker mag het werk niet voor commerciële doeleinden gebruiken.

Wageningen Economic Research aanvaardt geen aansprakelijkheid voor eventuele schade voortvloeiend uit het gebruik van de resultaten van dit onderzoek of de toepassing van de adviezen.

Wageningen Economic Research is ISO 9001:2008 gecertificeerd.

Wageningen Economic Research Rapport 2018-084 | Projectcode 2282500287

Foto omslag: Shutterstock 


\section{Inhoud}

Woord vooraf $\quad 5$

$\begin{array}{ll}\text { Samenvatting } & 6\end{array}$

S.1 Belangrijkste uitkomsten $\quad 6$

S.2 Overige uitkomsten $\quad 6$

$\begin{array}{ll}\text { S.3 Methode } & 7\end{array}$

$\begin{array}{ll}\text { Summary } & 8\end{array}$

$\begin{array}{lll}\text { S.1 Key findings } & 8\end{array}$

S.2 Complementary findings $\quad 8$

$\begin{array}{lll}\text { S.3 Method } & 9\end{array}$

$\begin{array}{lr}1 & \text { Inleiding } \\ \end{array}$

2 Methode $r 12$

2.1 Inleiding $\quad 12$

2.2 Invulling GLB 2021-2027: ruimte voor lidstaten 12

2.3 Keuzes voor Nederland 13

2.4 Scenario's $\quad 14$

2.5 Berekeningswijze 16

$\begin{array}{llr}3 & \text { Resultaten } & 20\end{array}$

$\begin{array}{lll}3.1 & \text { Inleiding } & 20\end{array}$

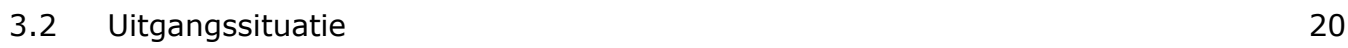

$\begin{array}{lll}3.3 & \text { Toeslagen per hectare in de nieuwe situatie } & 21\end{array}$

$\begin{array}{lll}3.4 & \text { Gevolgen voor het inkomen uit bedrijf } & 23\end{array}$

$\begin{array}{lll}3.5 & \text { Klimaatscore van de scenario's } & 25\end{array}$

$\begin{array}{llr}4 & \text { Slotbeschouwing } & 27\end{array}$

$\begin{array}{llr}5 & \text { Literatuur } & 30\end{array}$

Bijlage 1 Inkomen uit bedrijf in de vijf scenario's voor geselecteerde bedrijfstypen $\quad 31$

Bijlage 2 Omschrijving van de beheerpakketten in de eco-schema's 40 



\section{Woord vooraf}

Eind mei 2018 presenteerde de Europese Commissie (EC) nadere voorstellen over de invulling van het Gemeenschappelijk Landbouwbeleid (GLB) voor de periode na 2020. De eerste ideeën voor het GLB na 2020 zijn eind november 2017 naar buiten gebracht met het document De toekomst van voeding en landbouw (EC, 2017). Uit dit document zijn al een paar grote lijnen te destilleren in de mogelijke ontwikkeling van het GLB, zoals meer focus op het bevorderen van duurzaamheid, een evenwichtiger verdeling van de steun over de bedrijven en meer doelgerichte betalingen.

Deze doelstellingen zullen moeten worden gerealiseerd met een EU-budget dat naar verwachting lager zal zijn dan het nu is. De vaste commissie voor Landbouw, Natuur en Voedselkwaliteit van de Tweede Kamer der Staten-Generaal heeft behoefte aan een impact assessment van de effecten van de Europese voorstellen voor een nieuw GLB op het inkomen van de Nederlandse landbouw. Ook wil de commissie inzicht in hoe nationale keuzes voor invulling van de directe inkomenssteun deze gevolgen beïnvloeden.

Dit rapport schetst op basis van scenarioberekeningen het speelveld. De scenario's zijn tot stand gekomen in goed overleg met leden van de vaste commissie voor Landbouw, Natuur en Voedselkwaliteit van de Tweede Kamer der Staten-Generaal.

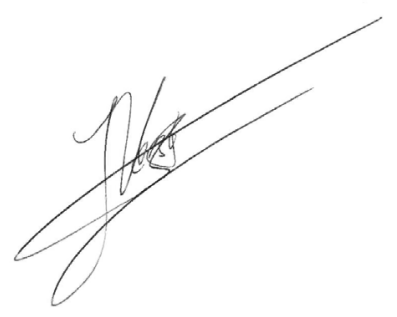

Prof.dr.ir. J.G.A.J. (Jack) van der Vorst Algemeen Directeur Social Sciences Group (SSG)

Wageningen University \& Research 


\section{Samenvatting}

\section{S.1 Belangrijkste uitkomsten}

De gevolgen van de voorgenomen herziening van het Gemeenschappelijk Landbouwbeleid voor de periode 2021-2027 voor het inkomen van de land- en tuinbouwbedrijven, zijn grotendeels afhankelijk van de keuzes die door Nederland worden gemaakt. Daarbij hebben sommige keuzes meer invloed dan andere. In de scenario's in deze studie is gewerkt met keuzes die een grotere invloed hebben. Bij alle cijfers moet worden bedacht dat het gaat om ruwe berekeningen, die gezien moeten worden als een eerste indicatie van mogelijke gevolgen, waarbij enkel de effecten van de eerste orde zijn meegenomen

In het basisscenario, min of meer een voortzetting van de huidige GLB-implementatie in 2014-2020, is het berekende gemiddelde inkomen in 2021 1\% lager dan in 2020. Dit wordt verklaard doordat het beschikbare toeslagbudget in 2021 met $4 \%$ daalt ten opzichte van 2020 . Het effect op het inkomen is beperkter omdat de toeslagen maar een deel van het inkomen vormen. Voor bedrijven waar de toeslagen een groter deel van het inkomen vormen, is het inkomenseffect groter. Dit geldt bijvoorbeeld voor melkveebedrijven $(-1,9 \%)$, zetmeelaardappelbedrijven $(-1,7 \%)$ en akkerbouwbedrijven $(-1,4 \%)$. De grootste veranderingen in het inkomen vinden plaats in de huidige implementatieperiode van het GLB (2014-2020), als gevolg van de convergentie van de toeslagen door de overstap van toeslagen op historische basis naar een flat rate.

In de voorstellen voor het nieuwe GLB kan een lidstaat kiezen om het bedrag dat de lidstaat ontvangt van de EU (de zogenaamde nationale envelop), in te zetten voor verschillende soorten toeslagen, waaronder een basisinkomenstoeslag en eco-schematoeslagen gericht op duurzaamheid. Ook heeft de lidstaat vrijheid wat betreft de invulling van de eco-schema's. Hoe groter het aandeel is van de nationale envelop dat wordt besteed aan eco-schema's en hoe zwaarder de eisen voor deelname aan eco-schema's, hoe groter de inkomensgevolgen kunnen zijn.

In de vier overige scenario's gaat het aandeel van de envelop voor de eerste pijler dat aan inkomenstoeslagen wordt besteed omlaag en het aandeel van de envelop voor eco-schematoeslagen omhoog. Ook variëren de scenario's in de zwaarte van de eco-schema's. In de scenario's is verondersteld dat hoe zwaarder het eco-schema is, hoe lager de deelnamebereidheid zal zijn. Deze veronderstellingen leiden tot lagere inkomenstoeslagen per ha en hogere eco-schematoeslagen. De eco-schematoeslag varieert van 205 euro per ha in het basisplus-scenario tot 1.650 euro in het zware eco-schemascenario. Voor de boeren die deelnemen aan een eco-schema kan dit leiden tot een hoger inkomen; hoeveel hoger is afhankelijk van de mate waarin de vergoeding de onkosten van deelname aan een maatregel compenseert en welk deel van de toeslag dus als inkomen resteert. Voor de groep niet-deelnemers neemt het inkomen gemiddeld af met 10 tot $20 \%$ in deze scenario's.

\section{S.2 Overige uitkomsten}

In hun Strategische Plannen voor de periode 2021-2027 voor het GLB moeten lidstaten aantonen dat de wijze waarop zij de toeslagen toekennen, bijdraagt aan de klimaatdoelstelling van het GLB. De klimaatscore wordt berekend volgens een formule waarbij sommige toeslagen zwaarder wegen dan andere. Hoe dichter bij 1 , hoe hoger de score van de lidstaat op de klimaatdoelstelling.

Bij de berekening van de klimaatscore van de gebruikte scenario's in deze studie zijn alleen de uitgaven van pijler 1 meegenomen en is pijler 2 buiten beschouwing gelaten. Het is daarom een partiële score. 
De klimaatscore van de uitgaven van pijler 1 in het basisscenario is 0,54 ; voor het basisplus-scenario is de uitkomst 0,65. De klimaatscores in het lichte eco-schemascenario, het zware eco-

schemascenario en het kringlooplandbouwscenario zijn het hoogst en komen alle drie op zo'n 0,8 uit. De klimaatscore is hoger naarmate het aandeel van de uitgaven aan eco-schematoeslagen in de envelop voor pijler 1 groter is.

De berekende eco-schematoeslag per ha is in alle scenario's over het algemeen lager dan de vergoedingen die nu worden gehanteerd in de natuur- en landschapspakketten. Dit betekent dat boeren maar een deel van hun landbouwareaal onder een pakket kunnen laten vallen.

\section{S.3 Methode}

In deze studie zijn vijf scenario's voor invulling van het GLB in de periode 2021-2027 doorgerekend op de gevolgen voor het inkomen van landbouwbedrijven in Nederland. Daarbij zijn 8 bedrijfstypen onderscheiden. Voor de doorrekening zijn data gebruikt uit het Bedrijveninformatienet van Wageningen Economic Research. Ook is op basis van deze berekeningen inzicht gegeven in de maximale hoogte van de eco-schematoeslag per ha en de mogelijke invulling daarvan, afgeleid uit de huidige beheerspakketten van de Subsidieregeling Agrarisch Natuur- en Landschapsbeheer. 


\section{Summary}

\section{S.1 Key findings}

The impact of the planned revision of the CAP for the 2021-2027 period on the income of agricultural and horticultural organisations largely depends on the choices made by the Netherlands. Some choices have more influence than others on the CAP's impact. In the scenarios in this study, choices with a greater influence were used. Please note that all figures are approximate and should be seen as a first indication of possible effects.

In the baseline scenario, which is more or less a continuation of the current CAP implementation for 2014-2020, the calculated average income in 2021 is $1 \%$ lower than in 2020 . This is explained by the fact that the available grant budget will fall by $4 \%$ in 2021 compared with 2020 . The effect on income is smaller, as the payments are only a part of income. For holdings whose payments account for a larger share of their income, the income effect is greater. As an example, this applies to dairy farms $(-1.9 \%)$, starch potato farms $(-1.7 \%)$ and arable farms $(-1.4 \%)$. The biggest changes in income will take place in the current period of implementation of the CAP (2014-2020), as a result of the convergence of payments due to the change from historical to flat-rate payments.

In the proposals for the new CAP, a Member State may choose to use the amount received by the Member State from the EU (the 'national envelope') for different types of payments, including a basic income support payment and ecological programmes aimed at sustainability. The Member State is also free to define the ecological programmes. The income consequences will increase as the share of the national envelope spent on ecological programmes rises together with more demanding requirements for participation in ecological programmes.

In the four other scenarios, the share of the envelope for the first pillar - which is spent on income payments - will be reduced and the share of the payments for ecological programmes in the envelope will be increased. The scenarios also vary in the impact of the ecological programmes. The scenarios assume that the more impactful the ecological programme is, the lower the willingness to participate will be. These assumptions lead to lower income payments per hectare and higher payments for ecological programmes. The payment for ecological programmes varies from $€ 205$ per hectare in the base plus scenario to $€ 1,650$ per hectare in the impactful ecological programme. For farmers participating in an ecological programme, this can lead to a higher income; the actual increase depends on how much the ecological programme payment compensates the costs incurred for participating in the programme. In other words, how much of the payment can be considered to contribute to the income. For the group of non-participants, the average income decreases by 10 to $20 \%$ in these scenarios.

\section{S.2 Complementary findings}

In their Strategic Plans for the 2021-2027 period for the CAP, Member States must demonstrate that the way in which they grant the payments contributes to the CAP's climate objective. The climate score is calculated according to a formula in which some payments weigh more heavily than others. The closer the score to 1 , the higher the Member State's score on the climate target.

Only expenditure under pillar 1 was used for the calculation of the climate score of the scenarios used in this study. Pillar 2 was therefore not taken into account, making this a partial score. 
The climate score for pillar 1 expenditure in the baseline scenario is 0.54 ; for the 'base plus' scenario the outcome is 0.65 . The climate scores in the light ecological programme scenario, the heavy ecological programme scenario and the cyclical agriculture scenario are the highest: all three result in around 0.8 . The higher the share of expenditure on ecological programme payments in the pillar 1 budget, the higher the climate score.

In all scenarios, the calculated ecological programme payment per hectare is generally lower than the payment currently used in nature and landscape packages. This means that farmers can only include part of their agricultural area in a package.

\section{S.3 Method}

In this study, five scenarios for the interpretation of the CAP in the period 2021-2027 were used to calculate the consequences for the income of agricultural organisations in the Netherlands. Eight organisational types were identified in these calculations. Data from Wageningen Economic Research's Farm Accountancy Data Network were used for the calculations. Based on these calculations, insight was also provided on the maximum amount of the ecological programme payment per hectare and its possible interpretation, derived from the current management packages of the subsidy scheme for agricultural nature and landscape management. 


\section{$1 \quad$ Inleiding}

Op 1 juni 2018 heeft de Europese Commissie (EC) haar wetgevende voorstellen voor het Gemeenschappelijk Landbouwbeleid (GLB) voor de jaren 2021-2027 gepresenteerd (EC, 2018a). In 2021-2027 zal het GLB op de volgende negen doelen zijn gericht: (1) zorgen voor een redelijk inkomen in de landbouw; (2) het concurrentievermogen van de landbouwsector vergroten; (3) het machtsevenwicht in de voedselketen herstellen; (4) bijdragen aan acties in verband met de klimaatverandering; (5) bijdragen aan milieuzorg; (6) landschappen en biodiversiteit in stand houden; (7) jonge boeren aantrekken; (8) bevorderen van vitale plattelandsgemeenschappen; en (9) beschermen van de kwaliteit van voedsel en gezondheid (EC, 2018b).

Deze doelen sluiten grotendeels aan bij de drie doelen van het huidige GLB: concurrerende voedselproductie, duurzaam beheer van natuurlijke hulpbronnen en klimaatacties, en een evenwichtige territoriale ontwikkeling. Ook de indeling in twee pijlers blijft bestaan, waarbij de eerste pijler zich richt op inkomenstoeslagen en sectorale steun en de tweede pijler op plattelandsontwikkeling.

Nieuw in het GLB is dat lidstaten bij de invulling van de toeslagen in de eerste pijler veel meer flexibiliteit krijgen en dat zij strategische plannen voor de implementatie van het GLB moeten opstellen. In die strategische plannen moeten lidstaten aangeven hoe zij met de toeslagen uit de eerste pijler en de maatregelen van de tweede pijler de negen GLB-doelen in hun land willen realiseren. Het gaat daarbij bijvoorbeeld om de verdeling van de nationale envelop van de eerste pijler over de diverse toeslagen, voorwaarden voor een goede landbouw- en milieupraktijk en voor vergroening, welke maatregelen uit de tweede pijler worden ingezet en welk budget voor die maatregelen wordt gereserveerd.

\section{Gevolgen flexibiliteit voor inkomens op de Nederlandse landbouwbedrijven}

De flexibiliteit in de toekenning van toeslagen in de eerste pijler houdt in dat lidstaten zelf een keuze moeten maken uit een menu van toeslagen en zelf kunnen bepalen welk aandeel van de nationale envelop, het bedrag dat Nederland van de EU ontvangt uit het Europees Landbouw Garantiefonds (ELFG), ze aan die toeslagen besteden. Wel geldt een aantal bindende voorwaarden, zoals een maximale omvang voor de toeslagen per bedrijf. Die flexibiliteit leidt ertoe dat boeren in verschillende lidstaten met een hele andere samenstelling van het pakket van toeslagen en daaraan verbonden voorwaarden te maken kunnen krijgen. De vaste commissie voor Landbouw, Natuur en Voedselkwaliteit van de Tweede Kamer der Staten-Generaal wil graag inzicht in de financiële gevolgen van de flexibiliteit in de eerste pijler van het GLB voor de inkomens op de Nederlandse landbouwbedrijven. Dit inzicht moet een antwoord geven op vragen als:

- Welke keuzes kan Nederland maken voor de toekenning van de verschillende toeslagen uit de eerste pijler?

- Wat betekenen deze keuzes voor de hoogte van de toeslagen die boeren ontvangen?

- Zijn er keuzes die grotere dan wel kleinere financiële gevolgen voor de landbouwinkomens hebben?

- Zijn er bedrijfstypen waar de financiële gevolgen van bepaalde keuzes groter zijn dan op andere bedrijfstypen?

Inzicht in de financiële gevolgen van verschillende manieren van toekenning van de toeslagen kan Nederland ondersteunen om weloverwogen keuzes te maken ten aanzien van de invulling van de toeslagen in de eerste pijler van het GLB.

\section{Onderzoeksvragen van deze studie}

De onderzoeksvragen van deze studie zijn:

- Hoe verandert de omvang van de ontvangen toeslagen per bedrijf bij verschillende keuzes voor de invulling van de toeslagen in de eerste pijler van het GLB in de periode 2021-2027? 
- Wat zijn de financiële gevolgen van die verschillende keuzes voor de inkomens op de Nederlandse landbouwbedrijven?

De onderzoeksvragen worden beantwoord door te werken met vijf scenario's voor de toekenning van toeslagen in de eerste pijler van het GLB in 2021. Daarbij worden veranderingen in de omvang van de ontvangen toeslagen per bedrijf en de gevolgen voor de landbouwinkomens gerelateerd aan de situatie in 2020 .

Opbouw van dit rapport

Hoofdstuk 2 beschrijft de methodologische aanpak van het onderzoek, waaronder de vijf scenario's en de berekeningswijze. Hoofdstuk 3 bevat de resultaten van de doorrekening van de vijf scenario's. Het laatste hoofdstuk geeft de conclusies en een beschouwing over hoe de eco-schema's in de verschillende scenario's kunnen worden ingevuld, gelet op de hoogte van de eco-schematoeslag per ha in elk scenario. 


\section{Methode}

\section{$2.1 \quad$ Inleiding}

Deze studie hanteert vijf scenario's om de gevolgen van verschillende keuzes voor de invulling van de eerste pijler van het GLB door te rekenen, voor de omvang van de toeslagen per ha en de inkomens op landbouwbedrijven. Paragraaf 2.2 schetst de speelruimte die Nederland volgens de wetgevende voorstellen voor het GLB 2021-2027 heeft bij de invulling van de toeslagen in de eerste pijler. Paragraaf 2.3 analyseert welke keuzes meer of minder invloed zullen hebben op het landbouwinkomen. Paragraaf 2.4 beschrijft de vijf scenario's. Paragraaf 2.5 bepreekt de uitgangspunten die zijn gehanteerd bij de doorrekening van de scenario's.

\subsection{Invulling GLB 2021-2027: ruimte voor lidstaten}

Voor de implementatie van het GLB in de periode 2021-2027 moet elke lidstaat een Strategisch Plan GLB 2021-2027 indienen (EC, 2018a). Lidstaten hebben daarbij veel eigen keuzemogelijkheden om op die manier maatwerk afgestemd op de specifieke situatie in hun land te kunnen leveren. Voor de toekenning van directe inkomenstoeslagen in de eerste pijler is er een aantal verplicht door de lidstaat in te voeren toeslagen en een aantal optionele toeslagen (tabel 2.1). Daarnaast moet ten minste $2 \%$ van het budget voor de eerste pijler worden besteed aan de doelstelling om jonge boeren aan te trekken en bedrijfsontwikkeling in plattelandsgebieden te vereenvoudigen. De lidstaat kan daarvoor kiezen uit interventies voor vestiging van jonge landbouwers, uit het opstarten van plattelandsbedrijven en uit aanvullende inkomenssteun voor jonge landbouwers.

Tabel 2.1 Toeslagen in de eerste pijler van het GLB, 2021-2027.

\begin{tabular}{lll} 
& Soort toeslag & $\begin{array}{c}\text { Voorgeschreven percentage } \\
\text { nationale envelop }\end{array}$ \\
\hline Verplicht & Basisinkomenstoeslag voor duurzaamheid & - \\
\hline & Redistributie-inkomenstoeslag voor duurzaamheid & - \\
\hline & Toeslag voor vrijwillige deelname aan eco-schema's & - \\
\hline Optioneel & Gekoppelde steun per ha of per dier & Maximaal $10 \%$ plus $2 \%$ voor \\
& & eiwitgewassen
\end{tabular}

Bron: EU-verordening 2018/392.

Voor de uitbetaling van toeslagen geldt:

- De toeslagen worden uitgekeerd als een gelijk bedrag per ha tenzij de lidstaat besluit het bedrag te baseren op betalingsrechten ${ }^{1}$ (art. 18). Toeslagen mogen regionaal worden gedifferentieerd.

- De redistributie-toeslag voorziet in een herverdeling van steun van grotere naar kleinere bedrijven en bedrijven van gemiddelde omvang. De redistributie-toeslag bestaat ook al in de huidige periode

\footnotetext{
1 In het Gemeenschappelijk Landbouw Beleid (GLB) van 2003 tot en met 2013 ging de EU over van een productieafhankelijke steun naar een bedrijfstoeslag. De zogenaamde toeslagrechten (ingevoerd per 1 januari 2006) werden gebaseerd op de betaalde subsidies in een referentieperiode (2000-2002), dus op historische betalingen. Per 2015 is Nederland van dit historisch model overgestapt naar een flat rate betaling per hectare. Hiermee zijn per 31 december 2014 de toeslagrechten vervallen en vervangen door een nieuw systeem van rechten, namelijk de betalingsrechten. Deze betalingsrechten zijn in 2015 toegekend. $\mathrm{Er}$ is in Nederland een overgangsperiode tot 1 januari 2019 afgesproken. De afbouw van het historische, bedrijfsspecifieke bedrag en de gelijktijdige opbouw naar een gelijk bedrag per hectare voor elke landbouwer verloopt dan geleidelijk (Meulen et al., 2017:12).
} 
2014-2020, maar is nu optioneel. Er zijn geen nadere EU-bepalingen voor het afbakenen van grotere en kleinere bedrijven.

- Toeslagen per boer die meer bedragen dan 60.000 euro worden gekort, waarbij de korting oploopt naarmate de toeslag hoger is (art. 15.1). Het budget verkregen door de korting moet met name worden gebruikt voor de redistributie-inkomenstoeslag voor duurzaamheid. Het bedrag mag ook worden toegevoegd aan het budget voor de tweede pijler.

- Lidstaten kunnen $15 \%$ van het budget voor de eerste pijler overhevelen naar dat van de tweede pijler; het omgekeerde is ook toegestaan (art. 90).

Nationale envelop voor de eerste pijler

De toeslagen in de eerste pijler van het GLB moeten uit de zogenaamde nationale envelop worden betaald. De nationale envelop wordt ook wel aangeduid als het budget voor de eerste pijler. De som van de nationale enveloppen in de komende periode $2021-2027$ is $7 \%$ lager dan die in periode $2014-$ 2020 (tabel 2.2).

Tabel 2.2 Nationale envelop voor de eerste pijler van het GLB voor Nederland, 2014-2027 (m/n. euro a).

\begin{tabular}{|c|c|c|c|c|c|c|c|}
\hline \multicolumn{8}{|c|}{ Periode 2014-2020 } \\
\hline 2014 & 2015 & 2016 & 2017 & 2018 & 2019 & 2020 & Totaal \\
\hline 781 & 781 & 768 & 756 & 744 & 732 & 732 & 5.295 \\
\hline 2021 & 2022 & 2023 & 2024 & 2025 & 2026 & 2027 & \\
\hline 704 & 704 & 704 & 704 & 704 & 704 & 704 & 4.927 \\
\hline \multicolumn{7}{|c|}{ Verschil totaal $2014-2020$ en totaal $2021-2027(\%)$} & $-6,9$ \\
\hline
\end{tabular}

a) In lopende prijzen.

Bron: Annex III van EU-verordening 1307/2013 en Annex en VII van EU-verordening 2018/392; bewerking Wageningen Economic Research.

\section{Klimaatscore}

Er gelden geen minimumeisen voor welk deel van de nationale envelop aan inkomens- en ecoschematoeslagen moet worden besteed. Wel moeten lidstaten in hun Strategisch Plan voor het GLB 2021-2027 aantonen dat de wijze waarop zij de toeslagen toekennen bijdraagt aan de klimaatdoelstelling van het GLB (art. 87). Daarvoor wordt een klimaatscore gebruikt, die afhangt van de aandelen van de uitgaven aan de diverse toeslagen en maatregelen in het totale budget voor de eerste en tweede pijler.

\subsection{Keuzes voor Nederland}

De lidstaten hebben veel keuzevrijheid bij de invulling van het GLB. Op voorhand is te beredeneren dat een aantal keuzes meer invloed zal hebben op de inkomens van de Nederlandse landbouwbedrijven dan andere.

Keuzes met geen tot beperkte invloed op de inkomens zijn:

- Uitbetalen op basis van een gelijk bedrag per ha dan wel op basis van betalingsrechten. De reden is dat Nederland bij de implementatie van de vorige hervorming van het GLB heeft gekozen voor het convergentiemodel, zodat tussen 2014 en 2019 in vijf gelijke stappen de historisch uiteenlopende betalingen op het niveau van de uniforme hectaretoeslag worden gebracht. De grootste veranderingen in het inkomen vinden daarom plaats in de huidige implementatieperiode van het GLB (2014-2020) omdat de hoogte van de betaling - die per ha zeer uiteen konden lopen - wordt gelijk getrokken (zie ook Meulen et al., 2017; Terluin et al., 2014).

- De aftopping van toeslagen per bedrijf van meer dan 60.000 euro. In Nederland zijn er weinig bedrijven die meer dan 60.000 euro per bedrijf aan toeslagen ontvangen. Het gemiddelde bedrag aan betalingsrechten lag in 2015 op 11.000 euro voor Nederland (Meulen et al., 2017). Bovendien is 
het zo dat de kosten voor meewerkende gezinsleden en loonarbeiders van de ontvangen toeslagen afgetrokken mogen worden, waardoor in de praktijk vermoedelijk geen enkel bedrijf in Nederland boven de 60.000 euro aan ontvangen toeslagen uitkomt.

Keuze waarvan effect op inkomens vooralsnog onduidelijk is:

- Herverdeling van grotere naar kleinere bedrijven (de redistributie-inkomenstoeslag). De Nederlandse bedrijven verschillen sterk in omvang gemeten naar standaardverdiencapaciteit. In hectare gemeten zijn deze verschillen minder groot. De aanname is dat van deze herverdeling een beperkt effect uitgaat (analoog aan de redenering bij de aftopping van toeslagen).

Keuzes met grote(re) invloed op inkomens zijn:

- Bij de scenario's voor de invoering van het GLB in Nederland kan worden gevarieerd met wisselende aandelen van de verschillende toeslagen in de nationale envelop; dit leidt tot inkomenseffecten en tot een hogere of lagere score op de klimaatdoelstelling.

- Het effect op het inkomen van de boer wordt mede bepaald door de vraag of hij deelneemt aan het eco-schema en de zwaarte van het eco-schema. De invulling van de eco-schema's heeft daarom grote invloed op de inkomens. De veronderstelling is ook dat als de lat hoger ligt, deelname beperkter zal zijn dan bij schema's waaraan deelname eenvoudiger is.

- Ook kan worden nagegaan wat het inkomenseffect is van de overheveling van $15 \%$ van het budget van de 'eerste' naar de 'tweede' pijler. $^{2}$ Overheveling van de tweede naar de eerste pijler heeft minder effect, omdat het bedrag voor de tweede pijler relatief beperkt is in vergelijking met de eerste pijler (voor Nederland circa $73 \mathrm{mln}$. euro per jaar voor de eerste pijler tegen circa $704 \mathrm{mln}$. euro per jaar voor de tweede pijler).

\subsection{Scenario's}

In het huidige GLB geeft Nederland 30\% van de nationale envelop uit aan vergroeningstoeslagen en $70 \%$ aan inkomenstoeslagen (inclusief de betalingen voor jonge boeren).

Volgens de wetgevende voorstellen voor het GLB 2021-2027 (EC, 2018) zijn lidstaten vrij om te bepalen welk deel van de nationale envelop aan de inkomenstoeslag en welk deel aan de ecoschematoeslag wordt besteed. Lidstaten zijn wel verplicht om als onderdeel van de eerste pijler zogenaamde eco-schema's aan te bieden, maar deelname is voor boeren vrijwillig. Als boeren deelnemen aan een eco-schema, ontvangen zij een toeslag. Bij dergelijke eco-schema's valt te denken aan de huidige vergroeningsmaatregelen in de eerste pijler of aan natuur- en landschapsbeheerpakketten uit de tweede pijler. Vanwege deze verplichting moet de envelop voor eco-schematoeslagen groter dan nul zijn.

Gelet op het GLB-doel van zorgen voor redelijke inkomens in de landbouw is de veronderstelling dat lidstaten ook een deel van de nationale envelop aan inkomenstoeslagen zullen besteden.

Deze overwegingen leiden tot vijf scenario's voor de toekenning van toeslagen in de eerste pijler van het GLB (tabel 2.3), waarbij is gevarieerd in de elementen die het meest effect zullen hebben op het landbouwinkomen. De scenario's zijn opgesteld in overleg met de vaste commissie voor Landbouw, Natuur en Voedselkwaliteit van de Tweede Kamer der Staten-Generaal. De gehanteerde percentages zijn gekozen op basis van de wens het speelveld zo goed mogelijk te verkennen. De scenario's worden hieronder toegelicht.

\footnotetext{
2 De vraag wat dit nationaal betekent voor de financiering van het GLB valt buiten het bestek van de studie.
} 


\begin{tabular}{|c|c|c|c|c|}
\hline Scenario & $\begin{array}{r}\text { Aandeel } \\
\text { inkomenstoeslag } \\
\text { in nationale } \\
\text { envelop }\end{array}$ & $\begin{array}{l}\text { Aandeel eco- } \\
\text { schematoeslag in } \\
\text { nationale envelop }\end{array}$ & $\begin{array}{l}\text { Overheveling budget } \\
\text { eerste pijler naar } \\
\text { tweede pijler }\end{array}$ & $\begin{array}{r}\text { Deelname boeren aan } \\
\text { eco-schema ( } \% \text { van } \\
\text { alle boeren) }\end{array}$ \\
\hline Basis & 70 & 30 & Nee & 100 \\
\hline Basisplus & 50 & 50 & Nee & 90 \\
\hline Zwaar eco-schema & 20 & 80 & $\mathrm{Ja}, 15 \%$ & 15 \\
\hline Kringlooplandbouw & 25 & 75 & $\mathrm{Ja}, 15 \%$ & 40 \\
\hline
\end{tabular}

a) Omwille van de eenvoud nemen we de $2 \%$ van het budget voor de jonge boeren mee in de inkomenstoeslag.

\section{Basisscenario}

Dit scenario gaat uit van de huidige situatie wat betreft de verdeling van het budget over de toeslagen: $70 \%$ van de nationale envelop wordt gebruikt voor de inkomenstoeslag en $30 \%$ voor de eco-schematoeslag. Alle bedrijven ontvangen een inkomenstoeslag en alle boeren krijgen een toeslag voor deelname aan een eco-schema. De eisen van het eco-schema zijn vergelijkbaar zijn met de huidige vergroeningseisen. De veronderstelling is dat de kosten voor deelname aan het schema beperkt zijn, daarom wordt de toeslag voor het eco-schema volledig als inkomen gerekend. Er vindt geen overheveling van het budget plaats tussen de pijlers.

\section{Basisplus-scenario}

Dit scenario gaat uit van een verdeling van het budget voor toeslagen van 50/50: 50\% van de nationale envelop wordt gebruikt voor de inkomenstoeslag en $50 \%$ voor de eco-schematoeslag. In dit scenario krijgen alle boeren een inkomenstoeslag en $90 \%$ van de boeren doet mee aan een ecoschema. Ten opzichte van de huidige vergroeningseisen, komt er één lichte vergroeningseis in het eco-schema bij. De veronderstelling is dat deze lichte eis leidt tot beperkte bijkomende kosten voor de ondernemer; deze zijn in de berekeningen niet meegenomen. De eco-schematoeslag wordt volledig meegenomen als inkomen. Er vindt geen overheveling van het budget plaats tussen de pijlers.

\section{Licht eco-schemascenario}

Dit scenario veronderstelt een forsere vergroening van de toeslagen. De verdeling van het budget voor toeslagen is 25/75: 25\% van de in 2021 beschikbare envelop voor de eerste pijler wordt gebruikt voor de inkomenstoeslag en $75 \%$ voor de eco-schematoeslag. Alle boeren ontvangen een inkomenstoeslag en $65 \%$ van de bedrijven neemt deel aan een eco-schema. De eco-schemaeisen zijn zwaarder dan die in het basisplus-scenario. Er vindt geen overheveling van het budget plaats tussen de pijlers.

In dit scenario wordt de eco-schematoeslag ingevuld op de wijze van de huidige agro-milieuklimaatmaatregelen, waarbij een boer een vergoeding ontvangt op basis van de (gemiddelde) kosten en de (gemiddeld) gederfde opbrengsten als gevolg van deelname aan de agro-milieuklimaatmaatregel. In de praktijk zal er per maatregel en per deelnemer variatie zijn in de mate waarin de vergoeding de onkosten van deelname aan een maatregel compenseert en welk deel van de toeslag als inkomen resteert. Binnen het kader van deze studie is het niet mogelijk deze kosten en opbrengstenderving in te schatten. Met het oog op het verkennen van het speelveld worden twee varianten doorgerekend. Variant a waarbij de eco-schematoeslag volledig kan worden toegerekend als inkomen; variant b waarin de eco-schematoeslag niet bijdraagt aan het inkomen, maar inkomensneutraal is.

\section{Zwaar eco-schemascenario}

Dit scenario zet zwaar in op vergroening van de toeslagen. Bovendien vindt er een overheveling plaats van $15 \%$ van het budget van de eerste naar de tweede pijler. In dit scenario wordt uitgegaan van een verdeling van het budget voor toeslagen van 20/80: 20\% van de beschikbare envelop wordt gebruikt voor de inkomenstoeslag en $80 \%$ voor de eco-schematoeslagen. Alle boeren krijgen een inkomenstoeslag en $15 \%$ van de bedrijven krijgen een toeslag voor deelname aan een eco-schema. De eco-schemaeisen zijn fors aangescherpt ten opzichte van de eisen voor het lichte eco-schema. 
Evenals voor het lichte eco-schemascenario worden twee varianten berekend, de variant waarbij de eco-schematoeslag volledig als inkomen wordt meegerekend en de variant waarbij deelname aan een eco-schema inkomensneutraal is.

\section{Kringlooplandbouwscenario}

Dit scenario gaat uit van een eco-schema gebaseerd op het gedachtegoed van de kringlooplandbouw. In de kringlooplandbouw wordt gestreefd naar minimale verliezen van grondstoffen bij de productie van biomassa. De inperking van verliezen kan worden gerealiseerd door reststromen te benutten en op te waarderen tot nuttige grondstoffen in het landbouwsysteem (Maas en Thijssen, 2018). De kringlooplandbouw is een integraal onderdeel van een circulair voedselsysteem en de bodem speelt een cruciale rol. Een goede bodemkwaliteit kan bijdragen aan een hogere opbrengst, dient als buffer voor extreme weersomstandigheden, en beperkt de verliezen van stikstof naar de lucht en het gronden oppervlaktewater. Verondersteld wordt dat het principe van kringlooplandbouw voor $40 \%$ van de Nederlands landbouwbedrijven haalbaar is. In dit scenario wordt een verdeling van het budget voor toeslagen van 25/75 gehanteerd: $25 \%$ van de beschikbare envelop wordt gebruikt voor de inkomenstoeslag en $75 \%$ voor de eco-schematoeslagen. In dit scenario krijgen alle boeren een inkomenstoeslag en $40 \%$ van de boeren neemt deel aan een eco-schema. Net als voor het lichte en zware eco-schema worden twee varianten doorgerekend, de variant waarbij de eco-schematoeslag volledig als inkomen wordt meegerekend en de variant waarbij deelname aan een eco-schema inkomensneutraal is.

Er vindt een overheveling plaats van $15 \%$ van het budget van de eerste naar de tweede pijler.

\subsection{Berekeningswijze}

Aannames over het landbouwinkomen, aantal ha en aantal bedrijven

Deze studie gebruikt data over het landbouwinkomen, het aantal ha landbouwareaal en het aantal landbouwbedrijven uit het Bedrijveninformatienet van Wageningen Economic Research. Het meest recente jaar waarvoor data beschikbaar zijn is 2016. De veronderstelling is dat het aantal ha landbouwareaal en het aantal landbouwbedrijven in de jaren daarna gelijk is aan dat van 2016, met de trendmatige afname van landbouwbedrijven wordt geen rekening gehouden. Omdat de landbouwinkomens in de landbouw van jaar tot jaar fluctueren, wordt voor het landbouwinkomen het vijfjaarlijks gemiddelde van 2012-2016 genomen. Dit inkomen is zowel inclusief als exclusief bedrijfstoeslagen van de eerste pijler van het GLB beschikbaar. De aanname is dat het gemiddelde inkomen exclusief bedrijfstoeslagen 2012-2016 in de jaren daarna nominaal constant blijft. Er wordt geen rekening gehouden met inflatie.

Convergentie van de toeslagen van de eerste pijler in de periode 2015-2019

Het Bedrijveninformatienet geeft data voor de bedrijfstoeslag uit de eerste pijler van het GLB per bedrijf in 2016. Deze bedrijfstoeslag zijn om te rekenen tot een premie per ha door de ontvangsten aan toeslagen per gemiddeld landbouwbedrijf te delen door het aantal ha landbouwareaal op dat gemiddelde bedrijf. De bedrijfstoeslagen uit de eerste pijler van het GLB convergeren in de periode 2015-2019 naar een uniforme premie per ha. De omvang van deze premie in 2019 is te berekenen door de nationale envelop voor de eerste pijler van het GLB in 2019 te delen door alle ha landbouwareaal in Nederland. Omdat de nationale envelop voor 2020 gelijk is aan die van 2019 en vanwege de veronderstelling dat het aantal ha landbouwareaal gelijk blijft na 2016, is de uniforme hectarepremie in 2020 gelijk aan die van 2019.

\section{Jonge boeren-toeslag}

De bedrijfstoeslagen van de eerste pijler van het GLB per gemiddeld landbouwbedrijf voor 2016 uit het Bedrijveninformatienet weerspiegelen de ontvangsten aan de inkomenstoeslag, de toeslag voor jonge boeren en de vergroeningstoeslag. Alle bedrijven ontvangen een inkomenstoeslag en een vergroeningstoeslag; bedrijven met een jonge boer als bedrijfshoofd kunnen een jonge boeren-toeslag krijgen. Omdat het gecompliceerd is om de jonge boeren-toeslag uit de bedrijfstoeslagen te elimineren en omdat er maximaal $2 \%$ van het budget voor de eerste pijler aan de jonge boeren-doelstelling mag 
worden besteed, is de jonge boeren-toeslag in deze studie buiten beschouwing gelaten en behandeld als inkomenstoeslag.

Beschikbare envelop voor inkomens- en eco-schematoeslagen

Uit de data van het Bedrijveninformatienet blijkt dat in 2016 zo'n 93\% ${ }^{3}$ van de nationale envelop werd gebruikt voor de inkomens- en vergroeningstoeslagen. Dit percentage is ook gehanteerd voor de nationale envelop van de andere jaren in deze studie. Dat betekent dat van de totale nationale envelop voor de eerste pijler van het GLB in 2021 van 704 miljoen euro, 657 euro beschikbaar is voor de inkomens- en eco-schematoeslagen (tabel 2.4).

Tabel 2.4 Beschikbaar bedrag voor de toeslagen uit de nationale envelop voor de eerste pijler van het GLB, 2021

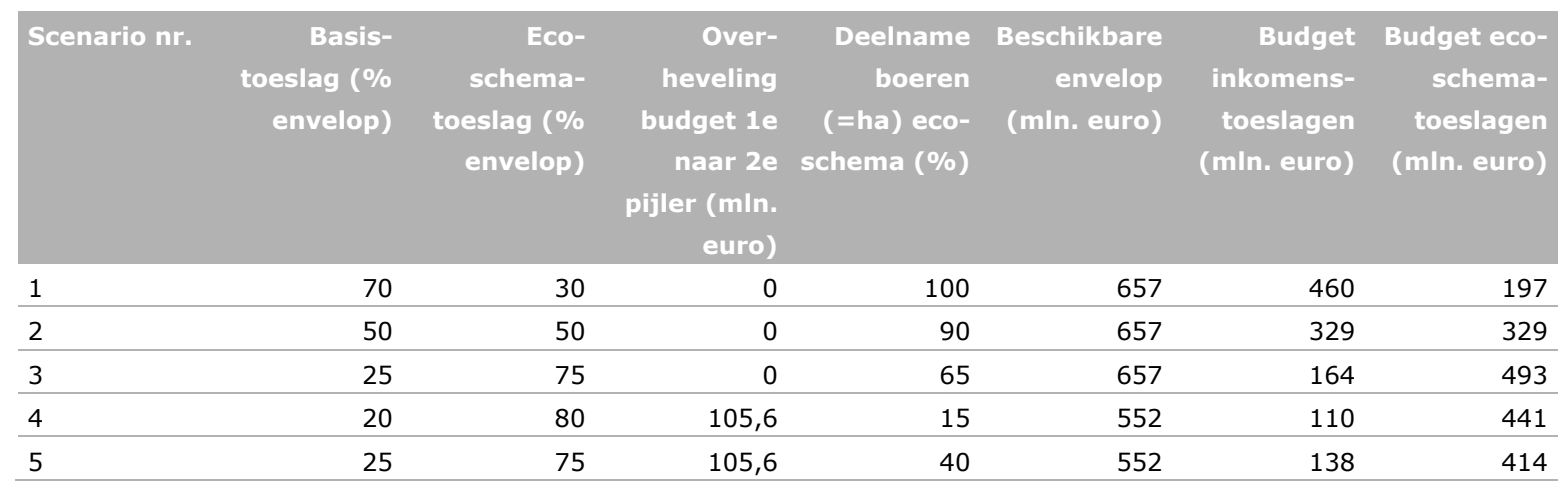

Bron: Annex III van EU-verordening 1307/2013 en Annex VII van EU-verordening 2018/392; bewerking Wageningen Economic Research.

Doorrekening van de scenario's voor het jaar 2021

De volgende periode van het GLB loopt van 2021-2027. In al die jaren is de nationale envelop voor toeslagen in de eerste pijler van het GLB in Nederland gelijk (tabel 2.2). Vanwege de veronderstelling dat de inkomens, het aantal bedrijven en het aantal ha landbouwareaal na 2016 gelijk blijven, geldt dit ook voor de omvang van de inkomenstoeslag per ha en de eco-schematoeslag per ha in de periode 2021-2027 in elk scenario. Deze studie berekent per scenario enkel de hoogte van de toeslagen per ha en de omvang van het landbouwinkomen voor 2021. In de jaren daarna zijn ze even hoog. De toeslagen per ha en het landbouwinkomen in het basisscenario in 2021 worden vergeleken met de situatie in 2020, het laatste jaar van de huidige GLB-periode.

\section{Berekening toeslagen per ha}

Op basis van data uit het Bedrijveninformatienet van Wageningen Economic Research is bekend hoeveel ha op Nederlandse landbouwbedrijven in de huidige situatie in aanmerking komt voor toeslagen. Boeren ontvangen voor alle ha een inkomenstoeslag: deze wordt afgeleid door het deel van de nationale envelop voor pijler 1 dat beschikbaar is voor inkomenstoeslagen te delen door dit aantal ha.

Het aantal ha waarvoor een eco-schematoeslag wordt toegekend hangt af van het percentage boeren dat deelneemt aan de eco-schema's. De eco-schemapremie wordt berekend door het deel van de nationale envelop dat beschikbaar is voor eco-schematoeslagen te delen door het product van alle ha en het deelnamepercentage aan het eco-schema. In het geval van het lichte eco-schemascenario: alle ha * 65\%. De hoogte van de eco-schematoeslag varieert in de verschillende scenario's. Op basis van de Groenblauwe Catalogus is een indicatie te geven van de eisen waaraan bij de verschillende ecoschematoeslagen kan worden gedacht.

\footnotetext{
3 Het verschil is vermoedelijk toe te schrijven aan kortingen voor onder meer de nationale reserve (zie ook Meulen et al., 2017:14).
} 


\section{Acht bedrijfstypes}

De effecten zullen worden berekend voor acht bedrijfstypes, waarbij de volgende typen worden onderscheiden:

- Akkerbouw (exclusief zetmeelaardappelen)

- Zetmeelaardappelen

- Melkveehouderij

- Vleeskalversector

- Overige graasdieren

- Hokdieren

- Tuinbouw

- Gemengde bedrijven.

De bedrijven zijn geclassificeerd op basis van de Standaard Output (genormaliseerde opbrengsten) (tabel 2.5). Alle bedrijven in Nederland zijn hierin meegenomen, uitgezonderd de zeer kleine bedrijven met een standaardopbrengst van minder dan 25.000 euro.

Tabel 2.5 Classificatie bedrijfstypen op basis van de Standaard Output (SO).

\begin{tabular}{ll}
$\begin{array}{l}\text { Akkerbouwbedrijven (exclusief } \\
\text { zetmeelaardappelen) }\end{array}$ & $\begin{array}{l}\text { Minimaal 2/3 van de SO bestaat uit akkerbouwgewassen en maximaal 1/3 uit } \\
\text { zetmeelaardappelen }\end{array}$ \\
\hline Zetmeelaardappelbedrijven & $\begin{array}{l}\text { Minimaal 2/3 van de SO bestaat uit akkerbouwgewassen en minimaal 1/3 uit } \\
\text { zetmeelaardappelen }\end{array}$ \\
\hline Melkveebedrijven & Minimaal 2/3 van de SO bestaat uit melk- en bijbehorende jongvee \\
\hline Vleeskalverbedrijven & Minimaal 2/3 van de SO bestaat uit vleeskalveren \\
\hline Overige graasdierbedrijven & $\begin{array}{l}\text { Minimaal 2/3 van de SO bestaat uit graasdieren (paarden, pony's, geiten, schapen, } \\
\text { vleesvee) melk- en bijbehorende jongvee zijn hiervan uitgesloten }\end{array}$ \\
\hline Hokdierbedrijven & Minimaal 2/3 van de SO bestaat uit varkens en/of pluimvee \\
\hline Tuinbouwbedrijven & $\begin{array}{l}\text { Minimaal 2/3 van de SO bestaat uit vormen van opengrond- of glastuinbouwgewassen } \\
\text { inclusief blijvende teelten (met name fruit) }\end{array}$ \\
\hline Gemengde bedrijven & $\begin{array}{l}\text { Indien niet aan de voorwaarde wordt voldaan van 2/3 akkerbouw, graasdieren, tuinbouw } \\
\text { of hokdieren dan valt het bedrijf in deze categorie }\end{array}$ \\
\hline
\end{tabular}

\section{Inkomen uit bedrijf}

Deze studie is gericht op het inkomen uit bedrijf: dat is de vergoeding die de ondernemers en hun huishoudens hebben behaald voor de inzet van hun arbeid en kapitaal in het bedrijf. Dit inkomen bestaat uit de totale opbrengsten van het bedrijf minus de betaalde kosten en afschrijvingen plus het saldo van buitengewone baten en lasten. Omdat er meerdere ondernemers/arbeidskrachten op één bedrijf kunnen werken, kan het inkomen uit bedrijf verschillen van het inkomen per arbeidskracht. Om de inkomens per ingezette arbeidskracht over bedrijven met elkaar te kunnen vergelijken, wordt het inkomen per bedrijf vaak uitgedrukt per onbetaalde arbeidsjaareenheid (oaje). Gemiddeld werkt er ongeveer één onbetaalde arbeidskracht voltijds op akkerbouwbedrijven, zetmeelaardappelbedrijven en overige graasdierbedrijven (tabel 2.6). Op die bedrijven ligt het inkomen uit bedrijf dicht bij het inkomen per arbeidskracht. Op melkveebedrijven, vleeskalverbedrijven en tuinbouwbedrijven werken gemiddeld 1,5 onbetaalde arbeidskrachteenheden. Daar is het inkomen per arbeidskracht dus lager dan het inkomen uit bedrijf. De bezetting van onbetaalde arbeidskrachteenheden op hokdierbedrijven en gemengde bedrijven ligt rond 1,3 . 
Tabel 2.6 Aantal onbetaalde arbeidsjaareenheden (oaje) per bedrijf op de 8 bedrijfstypen in deze studie, 2012-2016.

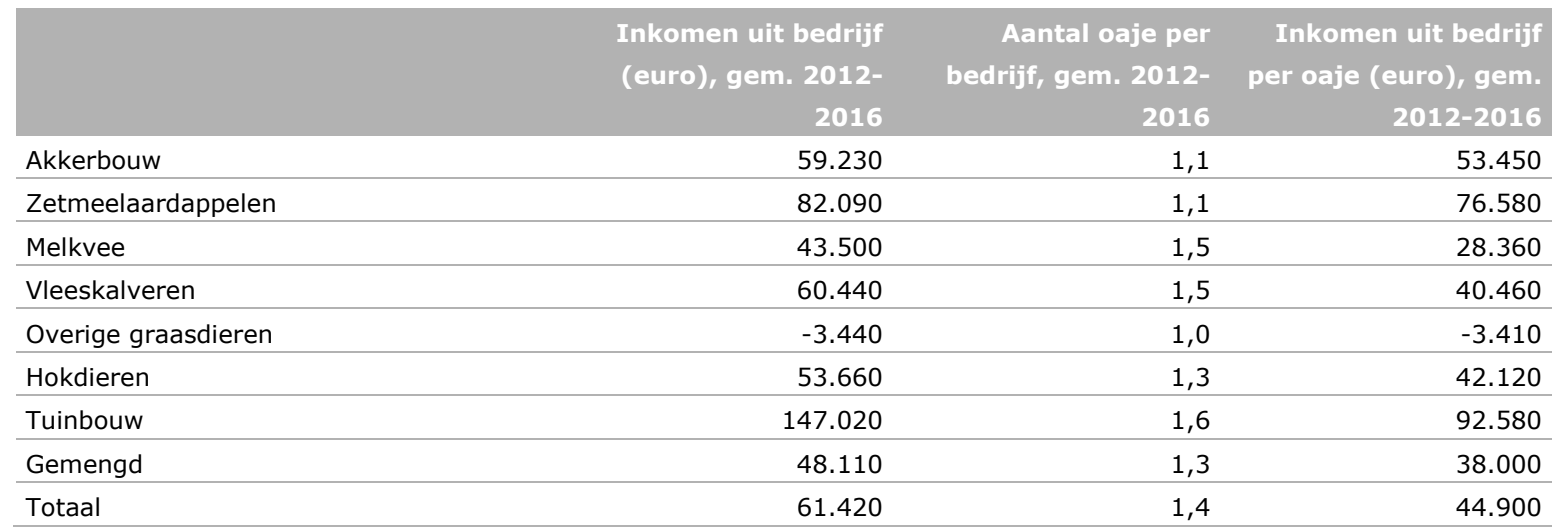

Bron: Bedrijveninformatienet. 


\section{Resultaten}

\subsection{Inleiding}

Dit hoofdstuk gaat in op de gevolgen van de vijf scenario's in deze studie voor de ontvangsten aan toeslagen uit de eerste pijler en de inkomens uit bedrijf op de verschillende bedrijfstypen in Nederland in 2021. Paragraaf 3.2 schetst de uitgangssituatie: hoeveel toeslagen ontvangen bedrijven in de huidige periode van het GLB en welk inkomen uit bedrijf wordt behaald? Paragraaf 3.3 analyseert hoe de inkomens- en eco-schematoeslagen per bedrijf veranderen in de scenario's. Paragraaf 3.4 behandelt de gevolgen voor het inkomen uit bedrijf in de scenario's, waarbij een onderscheid wordt gemaakt naar inkomens op bedrijven die wel of niet meedoen aan een eco-schema. De laatste paragraaf licht de klimaatscore van elk scenario toe. Bij alle cijfers moet worden bedacht dat het gaat om ruwe berekeningen, die gezien moeten worden als een eerste indicatie van mogelijke effecten.

\subsection{Uitgangssituatie}

Toeslagen per ha in 2016

Het meest recente jaar waarvoor data voor inkomens uit bedrijf en ontvangsten aan GLB-toeslagen beschikbaar zijn is 2016. In dat jaar ontvingen ruim 46.000 landbouwbedrijven een toeslag uit de eerste pijler van het GLB. Omdat Nederland de GLB-toeslagen in de periode 2015-2019 laat convergeren naar een uniforme hectarepremie, bestaan er tot 2019 tussen bedrijven verschillen in de ontvangen toeslag per ha. Deze verschillen hangen samen met de hoogte van de toeslagen die de bedrijven vóór 2015 kregen; deze hoogte was gebaseerd op de historische productie (in hectares of dieren gemeten). Vleeskalverbedrijven en zetmeelaardappelbedrijven ontvingen in 2016 de hoogste toeslag per ha; tuinbouwbedrijven en gemengde bedrijven de laagste (tabel 3.1). De toeslagen in de vleeskalverensector zijn zo hoog per ha omdat deze bedrijven over het algemeen nauwelijks grond bezitten, voor de tuinbouwbedrijven zijn deze laag omdat het merendeel van de tuinbouwsector geen steun ontving voor de laatste hervorming (zie ook Jongeneel et al., 2011). De toeslagen op de overige bedrijfstypen lagen rond de gemiddelde toeslag van zo'n 400 euro per ha.

Tabel 3.1 Enkele kenmerken van de acht bedrijfstypen in deze studie, 2012-2016.

\begin{tabular}{|c|c|c|c|c|c|c|}
\hline & $\begin{array}{r}\text { Aantal } \\
\text { bedrijven, } \\
2016\end{array}$ & $\begin{array}{r}\text { Hectares } \\
\text { per } \\
\text { bedrijf, } \\
2016\end{array}$ & $\begin{array}{r}\text { Inkomen uit } \\
\text { bedrijf (euro), } \\
\text { gem. } 2012- \\
2016\end{array}$ & $\begin{array}{r}\text { Gemiddelde } \\
\text { ontvangsten } \\
\text { toeslagen } \\
\text { eerste pijler } \\
\text { GLB per } \\
\text { bedrijf } \\
\text { (euro), } 2016\end{array}$ & $\begin{array}{r}\text { Toeslagen } \\
\text { eerste pijler } \\
\text { GLB als\% } \\
\text { inkomen uit } \\
\text { bedrijf, } 2016\end{array}$ & $\begin{array}{r}\text { Omgerekende } \\
\text { bedrijfstoeslag } \\
\text { per ha (euro), } \\
2016\end{array}$ \\
\hline Akkerbouw a) & 6.553 & 58 & 59.230 & 21.860 & 37 & 379 \\
\hline Zetmeelaardappelen & 781 & 81 & 82.090 & 45.130 & 55 & 555 \\
\hline Melkvee & 16.436 & 55 & 43.500 & 23.020 & 53 & 418 \\
\hline Vleeskalveren & 677 & 8 & 60.440 & 30.750 & 51 & 3.755 \\
\hline Overige graasdieren & 5.462 & 22 & -3.440 & 7.960 & 231 & 359 \\
\hline Gemengd & 2.951 & 43 & 48.110 & 14.290 & 30 & 331 \\
\hline Totaal & 45.895 & 39 & 61.420 & 15.620 & 25 & 402 \\
\hline
\end{tabular}

a) Exclusief zetmeelaardappelbedrijven; b) Inclusief glastuinbouwbedrijven.

Bron: Bedrijveninformatienet. 


\section{Inkomens uit bedrijf in 2012-2016}

Omdat de inkomens in de landbouw van jaar tot jaar aanzienlijk kunnen fluctueren, wordt vaak met een meerjarig gemiddeld inkomen gewerkt. In deze studie is dat het vijfjaarlijks gemiddelde inkomen van 2012-2016. Gemiddeld bedroeg het inkomen uit bedrijf in 2012-2016 ruim 61.000 euro. Tussen de bedrijfstypen bestaan grote verschillen in het gemiddelde gezinsinkomen: het was negatief op de overige graasdierbedrijven en het hoogst op de tuinbouwbedrijven (tabel 3.1). Ongeveer een kwart van het inkomen op alle bedrijven is afkomstig van de GLB-toeslagen; zonder deze toeslagen zou ceteris paribus - het inkomen uit bedrijf in 2012-2016 op zo'n 45.000 euro uitkomen. Het aandeel van de GLB-toeslagen in het inkomen verschilt aanzienlijk tussen de bedrijfstypen: van enkele procenten op tuinbouwbedrijven en hokdierbedrijven tot meer dan de helft op vleeskalverbedrijven, melkveebedrijven en zetmeelaardappelbedrijven. Op de overige graasdierbedrijven zijn de toeslagen ruim twee keer zo groot als het inkomen uit bedrijf; zonder toeslagen zou het inkomen op die bedrijven negatiever zijn.

\section{Uniforme hectarepremie in 2019}

Tussen 2015 en 2019 convergeren de toeslagen van de eerste pijler van het GLB naar een uniforme hectarepremie. Dat betekent dat elk landbouwbedrijf in 2019 eenzelfde bedrag per ha aan inkomensen eco-schematoeslagen krijgt van zo'n 383 euro (tabel 3.2). Bedrijven die in 2016 meer krijgen dan de nationaal gemiddelde hectaretoeslag zullen hun ontvangsten aan toeslagen in de periode 20162019 zien teruglopen, terwijl bedrijven die in 2016 minder dan de gemiddelde toeslag ontvangen juist een hoger bedrag aan toeslagen krijgen. Vooral op de vleeskalverbedrijven, de zetmeelaardappelbedrijven en de tuinbouwbedrijven leidt dit tot grote veranderingen: op de vleeskalverbedrijven en de zetmeelaardappelbedrijven gaan de ontvangsten aan toeslagen tussen 2016 en 2019 fors naar beneden; op tuinbouwbedrijven zijn de ontvangsten aan toeslagen in 2019 daarentegen ruim twee keer zo hoog als in 2016. De hoogte van de uniforme hectarepremie in 2020 is gelijk aan die van 2019 omdat de nationale envelop voor 2020 net zo groot is als die voor 2019.

Tabel 3.2 Gemiddelde ontvangsten aan toeslagen uit de eerste pijler GLB per bedrijf, 2016 en 2019 (euro).

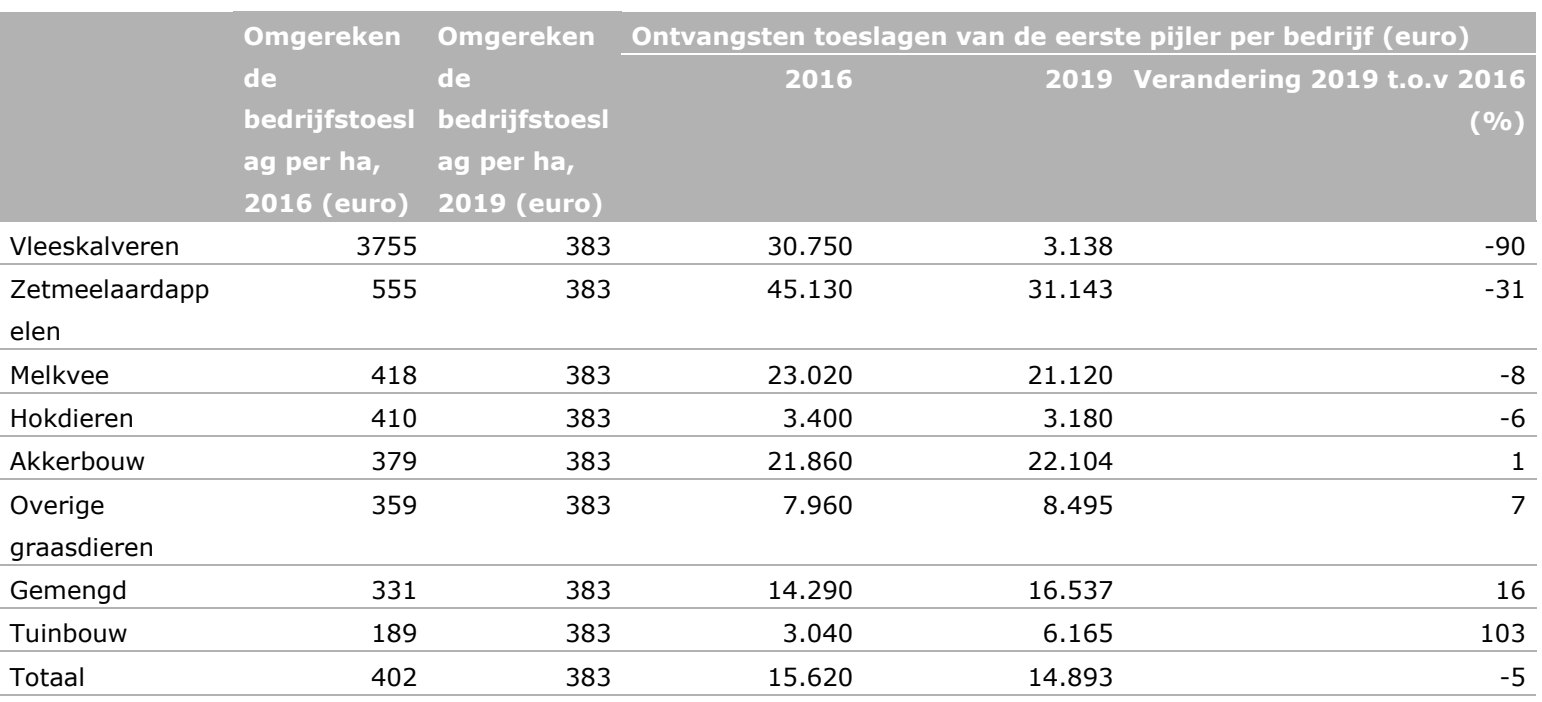

\subsection{Toeslagen per hectare in de nieuwe situatie}

De gevolgen van de scenario's voor de omvang van de GLB-toeslagen en de inkomens uit bedrijf zijn berekend voor het jaar 2021. De situatie in 2016 is de proxy voor 2021, omdat voor 2021 nog geen inkomen bekend is, evenmin als hoeveel landbouwbedrijven er van de verschillende bedrijfstypen dan zullen zijn. Het inkomen exclusief toeslagen in 2021 is daarom gelijk aan het gemiddelde inkomen exclusief toeslagen in 2012-2016, het aantal bedrijven in 2021 is hetzelfde als in 2016. Het aantal ha per bedrijf in 2021 verandert evenmin ten opzichte van 2016. 
De scenario's zijn samengesteld aan de hand van de volgende drie criteria:

- Het aandeel van de nationale envelop dat aan inkomenstoeslagen en eco-schematoeslagen wordt besteed.

- Het percentage boeren dat deelneemt aan het eco-schema.

- Het percentage van de nationale envelop voor de eerste pijler van het GLB dat wordt overgeheveld naar het budget van de tweede pijler.

Eco-schematoeslag per ha stijgt als minder boeren deelnemen aan eco-schema

In het basisscenario krijgen alle boeren zowel een inkomenstoeslag als een eco-schematoeslag. Iedereen neemt deel aan het eco-schema, dat vergelijkbaar is met de huidige vergroeningseisen. Elke boer ontvangt dan een inkomenstoeslag van 258 euro en een eco-schematoeslag van 111 euro (tabel 3.3). In de overige vier scenario's wordt relatief minder budget voor inkomenstoeslagen en meer budget gereserveerd voor eco-schematoeslagen, en doen er minder boeren mee aan de ecoschema's vanwege hogere eisen. Daardoor gaat de inkomenstoeslag omlaag: hij varieert van 184 euro per ha in het basisplus-scenario tot 62 euro in het zware eco-schemascenario. De eco-schematoeslag per ha gaat daarentegen omhoog: van 205 euro per ha in het basisplus-scenario tot 1.650 euro in het zware eco-schemascenario. In dat laatste scenario doen $15 \%$ van de boeren mee aan een eco-schema op $15 \%$ van het landbouwareaal. Op een aanzienlijk deel van het landbouwareaal worden in dit scenario dus geen extra inspanningen op het gebied van milieu, landschap en klimaat geleverd.

Tabel 3.3 Inkomenstoeslag en eco-schematoeslag in elk scenario, 2021.

\begin{tabular}{|c|c|c|c|c|c|}
\hline Scenario & $\begin{array}{r}\text { Inkomens- } \\
\text { toeslag (euro } \\
\text { per ha) }\end{array}$ & $\begin{array}{r}\text { Eco-schema- } \\
\text { toeslag (euro } \\
\text { per ha) }\end{array}$ & $\begin{array}{r}\text { Aantal ha met } \\
\text { eco-schema- } \\
\text { toeslag } \\
(* 1.000)\end{array}$ & $\begin{array}{r}\text { Ha met eco- } \\
\text { schema- } \\
\text { toeslag als\% } \\
\text { van totaal } \\
\text { areaal }\end{array}$ & $\begin{array}{r}\text { Inkomens- } \\
\text { toeslag plus } \\
\text { eco-schema- } \\
\text { toeslag (euro } \\
\text { per ha) }\end{array}$ \\
\hline Basis & 258 & 111 & 1.784 & 100 & 369 \\
\hline Licht eco-schema & 92 & 425 & 1.160 & 65 & 517 \\
\hline Zwaar eco-schema & 62 & 1.650 & 268 & 15 & 1.711 \\
\hline Kringlooplandbouw & 77 & 580 & 714 & 40 & 657 \\
\hline
\end{tabular}

\section{Bandbreedte hoogte eco-schematoeslag}

Door variaties in de omvang van de envelop die aan eco-schematoeslagen wordt besteed en het aantal boeren dat deelneemt aan een eco-schema, kan de hoogte van de eco-schematoeslag per ha lager dan wel hoger uitkomen. In de scenario's in deze studie varieert de eco-schematoeslag van 1111.650 euro (tabel 3.3). Dit is echter niet de maximale bandbreedte waarbinnen de eco-schematoeslag per ha kan variëren. Strikt genomen bestaat die ook niet omdat in de voorstellen van de EC eisen ontbreken voor de aandelen van de nationale envelop die minimaal aan de inkomens- en ecoschematoeslagen moeten worden besteed.

Stel dat als ondergrens voor de eco-schematoeslag wordt uitgegaan van:

- Een overheveling van $15 \%$ van de envelop van de eerste pijler naar de tweede pijler.

- Een aandeel van $10 \%$ van de resterende nationale envelop voor de eerste pijler voor ecoschematoeslagen.

- Een deelname van alle boeren aan de eco-schema.

En als bovengrens wordt uitgegaan van:

- Een aandeel van $90 \%$ van de nationale envelop voor eco-schematoeslagen.

- Een deelname van $10 \%$ van de boeren aan de eco-schema.

Dan is de minimum-eco-schematoeslag 31 euro per ha ( 55 miljoen euro/1,78 miljoen ha) en de maximum-eco-schematoeslag 3.315 euro per ha (591 miljoen euro/178.000 ha). 
Toeslag per ha in basisscenario 4\% lager dan in 2020

In het basisscenario ontvangt elke boer in 2021 een uniforme hectarepremie van 369 euro per ha (inkomenstoeslag plus eco-schematoeslag) (tabel 3.2). In vergelijking met de hectarepremie van 383 euro in 2020 betekent dat een daling van 4\%. Dit komt omdat de nationale envelop die in het basisscenario beschikbaar is voor de inkomens- en eco-schematoeslag 4\% lager is dan die van 2020.

\subsection{Gevolgen voor het inkomen uit bedrijf}

Inkomens in basisscenario zo'n 1\% lager dan in 2020

Voor alle bedrijven gemiddeld nemen de inkomens uit bedrijf in het basisscenario met zo'n $1 \%$ af ten opzichte van de inkomens in 2020 (tabel 3.4). Op sommige bedrijfstypes, zoals overige graasdierbedrijven $(-11,2 \%)$, melkveebedrijven $(-1,9 \%)$ zetmeelaardappelbedrijven $(-1,7 \%)$, akkerbouwbedrijven $(-1,4 \%)$ en gemengde bedrijven $(-1,3 \%)$ is de afname wat groter en die op hokdierbedrijven en tuinbouwbedrijven (beide $-0,2 \%)$ en vleeskalverbedrijven $(-0,4 \%)$ kleiner. De mate waarin het inkomen uit bedrijf meer dan wel minder wordt beïnvloed door een wijziging in de ontvangsten aan toeslagen uit de eerste pijler van het GLB hangt samen met het aandeel van deze toeslagen in het inkomen: hoe hoger dit aandeel, hoe meer het inkomen daalt bij een verlaging van de toeslagen (tabel 3.5).

Tabel 3.4 2020 a).

\begin{tabular}{|c|c|c|c|c|c|c|}
\hline & $\begin{array}{r}\text { Inkomen } \\
\text { uit bedrijf } \\
\text { zonder } \\
\text { toeslagen } \\
\text { (euro), } \\
\text { gem. } 2012- \\
2016\end{array}$ & $\begin{array}{r}\text { Gemiddelde } \\
\text { ontvangsten } \\
\text { toeslagen } \\
\text { eerste pijler } \\
\text { GLB per } \\
\text { bedrijf } \\
\text { (euro), } 2020\end{array}$ & $\begin{array}{r}\text { Gemiddelde } \\
\text { ontvangsten } \\
\text { toeslagen } \\
\text { eerste pijler } \\
\text { GLB per } \\
\text { bedrijf (euro), } \\
2021\end{array}$ & $\begin{array}{r}\text { Inkomen uit } \\
\text { bedrijf (incl. } \\
\text { toeslagen) } \\
\text { (euro), gem. } \\
2020\end{array}$ & $\begin{array}{l}\text { Inkomen uit } \\
\text { bedrijf (incl. } \\
\text { toeslagen) } \\
\text { (euro), } 2021\end{array}$ & $\begin{array}{r}\text { Verandering } \\
\text { inkomen } \\
2021 \text { ten } \\
\text { opzichte van } \\
2020(\%)\end{array}$ \\
\hline Akkerbouw & 37.370 & 22.104 & 21.259 & 59.474 & 58.629 & $-1,4$ \\
\hline Zetmeelaardappelen & 36.960 & 31.143 & 29.952 & 68.103 & 66.912 & $-1,7$ \\
\hline Melkvee & 20.480 & 21.120 & 20.312 & 41.600 & 40.792 & $-1,9$ \\
\hline Vleeskalveren & 29.690 & 3.138 & 3.018 & 32.828 & 32.708 & $-0,4$ \\
\hline Overige graasdieren & -11.400 & 8.495 & 8.170 & -2.905 & -3.230 & $-11,2$ \\
\hline Hokdieren & 50.260 & 3.180 & 3.059 & 53.440 & 53.319 & $-0,2$ \\
\hline Tuinbouw & 143.980 & 6.165 & 5.929 & 150.145 & 149.909 & $-0,2$ \\
\hline Gemengd & 33.820 & 16.537 & 15.904 & 50.357 & 49.724 & $-1,3$ \\
\hline Totaal & 45.800 & 14.893 & 14.324 & 60.693 & 60.124 & $-0,9$ \\
\hline
\end{tabular}

a) Zie ook Bijlage 1 voor een compleet overzicht van de inkomensgevolgen per scenario per bedrijfstype.

Tabel 3.5 Aandeel toeslagen in het inkomen uit bedrijf, 2020 en 2021 (basisscenario) (\% ).

\begin{tabular}{lrr} 
& 2020 & 2021 (basis scenario) \\
Akkerbouw & 37 & 36 \\
\hline Zetmeelaardappelen & 46 & 45 \\
\hline Melkvee & 51 & 50 \\
\hline Vleeskalveren & 10 & 292 \\
\hline Overige graasdieren a) & 6 & 253 \\
\hline Hokdieren & 4 & 4 \\
\hline Tuinbouw & 33 & \\
\hline Gemengd & 32 & \\
\hline Totaal & 25 & 24 \\
\hline
\end{tabular}

a) Omdat het inkomen negatief is in de uitgangssituatie, is de relatieve verandering groot. 
Inkomen in het basisscenario gebruikt als referentie-inkomen

Het inkomen uit bedrijf in het basisscenario, waarbij boeren zowel een inkomens- als een ecoschematoeslag ontvangen, is als referentie-inkomen gebruikt om na te gaan hoe de inkomens veranderen in de verschillende scenario's. Daarbij is onderscheid gemaakt tussen bedrijven die alleen een inkomenstoeslag ontvangen en bedrijven die wegens deelname aan een eco-schema daarnaast een eco-schematoeslag ontvangen.

Inkomens op bedrijven zonder eco-schema dalen met 10-20\%

In het basisplus-scenario loopt het inkomen uit bedrijf gemiddeld met ruim $10 \%$ terug op bedrijven die alleen een inkomenstoeslag ontvangen in vergelijking met het basisscenario (tabel 3.6). In de lichte en zware eco-schemascenario's en het kringlooplandbouwscenario dalen de inkomens uit bedrijf gemiddeld tot circa $80 \%$ van dat in het basisscenario. Die daling komt doordat de beschikbare envelop voor inkomenstoeslagen veel kleiner is dan die in het basisscenario. De inkomens uit bedrijf op de akkerbouwbedrijven, zetmeelaardappelbedrijven, melkveebedrijven, overige graasdierbedrijven en gemengde bedrijven nemen bovengemiddeld af in de scenario's; dat heeft te maken met een relatief groot aantal ha op deze bedrijfstypen en een relatief hoog aandeel van de toeslagen in het inkomen. Op de overige graasdierbedrijven, die in het basisscenario een negatief inkomen uit bedrijf hebben, worden de inkomens nog meer negatief: ze variëren van ruim -7.000 euro in het basisplus-scenario tot zo'n -10.000 euro in het zware eco-schemascenario.

Tabel 3.6 Veranderingen in het inkomen uit bedrijf op bedrijven die alleen een inkomenstoeslag ontvangen, index inkomen inclusief inkomens- en eco-schematoeslag in het basisscenario $=100$.

\begin{tabular}{|c|c|c|c|c|}
\hline & & & & Scenario \\
\hline & 2. Basisplus & 3. Licht eco-schema & 4. Zwaar eco-schema & 5. Kringlooplandbouw \\
\hline Akkerbouw & 82 & 73 & 70 & 71 \\
\hline Melkvee & 75 & 63 & 59 & 61 \\
\hline Vleeskalveren & 95 & 93 & 92 & 93 \\
\hline Hokdieren & 97 & 96 & 95 & 95 \\
\hline Tuinbouw & 98 & 97 & 97 & 97 \\
\hline Gemengd & 84 & 76 & 73 & 75 \\
\hline Totaal & 88 & 82 & 80 & 81 \\
\hline
\end{tabular}

a) Omdat het inkomen negatief is in de uitgangssituatie, is de relatieve verandering groot.

Inkomens op bedrijven met eco-schema stijgen

In het basisscenario doen alle boeren verplicht mee aan een eco-schema. In de overige scenario's is deelname aan een eco-schema vrijwillig en is de eco-schematoeslag hoger dan in het basisscenario. In het basisplus-scenario liggen de inkomens op bedrijven die deelnemen aan een eco-schema gemiddeld een fractie hoger dan in het basisscenario (tabel 3.7). Zoals aangegeven in paragraaf 2.4 is in dit scenario de veronderstelling dat de kosten voor deelname gering zijn en de toeslag volledig als inkomen kan worden gezien.

In de drie scenario's waar de eisen voor deelname aan een schema zwaarder zijn - het lichte ecoschema, het zware ecoschema en het kringloopschema - komen de inkomens uit bedrijf in het lichte eco-schemascenario gemiddeld zo'n $10 \%$ hoger uit dan in het basisscenario, in het kringlooplandbouwscenario zijn de inkomens gemiddeld bijna een vijfde hoger en in het zware ecoschemascenario ruim vier vijfde. Daarbij zijn de eco-schematoeslagen volledig toegerekend als inkomen (variant a). Dit betekent dat de in tabel 3.7 (en bijlage 1) gepresenteerde inkomensstijgingen een overschatting zijn. Immers, zeker in de situatie dat deelname aan een eco-schema meer eisen met zich meebrengt, zal dit leiden tot hogere kosten. In de situatie dat de eco-schematoeslag als inkomensneutraal wordt meegenomen (variant b), zijn de inkomenseffecten gelijk aan de situatie dat een bedrijf enkel een inkomenstoeslag krijgt (zie tabel 3.6 en voorgaande alinea). Deze twee uitersten geven de randen van het speelveld aan. Ter illustratie voor een situatie binnen die uitersten van het 
speelveld: stel dat $10 \%$ van de toeslag resteert als inkomen; in vergelijking met de situatie zonder ecoschematoeslag, stijgt het totale inkomen dan met enkele procenten in de drie scenario's.

Tabel 3.7 Veranderingen in het inkomen uit bedrijf op bedrijven die zowel een inkomens als een eco-schematoeslag ontvangen, index inkomen inclusief inkomens- en eco-schematoeslag in het basisscenario $=100 a$ )

\begin{tabular}{lrrrr} 
& & & \\
& & & Scenario \\
Akkerbouw & 2. Basisplus & 3. Licht eco-schema & 4. Zwaar eco-schema & 5. Kringlooplandbouw \\
\hline Zetmeelaardappelen & 102 & 115 & 232 & 128 \\
\hline Melkvee & 102 & 118 & 263 & 281 \\
\hline Vleeskalveren & 103 & 120 & 134 & 822 \\
\hline Overige graasdieren & 101 & 104 & 139 \\
\hline Hokdieren & -86 & 21 & 107 \\
\hline Tuinbouw & 100 & 102 & 114 \\
\hline Gemengd & 100 & 102 & 217 \\
\hline Totaal & 102 & 113 & 104 \\
\hline
\end{tabular}

a) In deze cijfers is de eco-schematoeslag volledig meegerekend als inkomen en is geen rekening gehouden met eventuele kosten om aan het schema te voldoen.

\subsection{Klimaatscore van de scenario's}

In hun Strategische Plannen voor het GLB in de periode 2021-2027 moeten lidstaten aantonen dat de wijze waarop zij de toeslagen toekennen bijdraagt aan de klimaatdoelstelling van het GLB (art. 87 van EU-verordening 2018/392). Daarbij wegen sommige soorten inkomenstoeslagen zwaarder dan andere. De regel die de EC hanteert voor de beoordeling van het halen van de klimaatdoelstelling is het quotiënt van:

- de som van de volgende vijf posten:

- $40 \%$ van de uitgaven voor de inkomenstoeslag en de redistributie-inkomenstoeslag

- $100 \%$ van de uitgaven voor de eco-schematoeslag voor vrijwillige deelname aan eco-schema's

- 40\% van de uitgaven voor de aanvullende inkomenstoeslag voor jonge boeren in pijler 1

- $100 \%$ van de uitgaven voor klimaat-, duurzaamheids- en milieumaatregelen in pijler 2

- $40 \%$ van de uitgaven voor gebieden met een natuurlijke handicap in pijler 2

- Gedeeld door de som van het budget voor pijler 1 en pijler 2 in jaar $x$

Hoe dichter dit quotiënt bij 1 ligt, hoe hoger de score van de lidstaat op de klimaatdoelstelling.

Bij de berekening van de klimaatscore van de gebruikte scenario's in deze studie zijn alleen de uitgaven van pijler 1 meegenomen en is pijler 2 buiten beschouwing gelaten. Het is daarom een partiële score. Het budget voor pijler 2 is relatief klein ten opzichte van het budget voor pijler 1 , de uitgaven en het budget voor pijler 2 hebben daarom weinig invloed op de hoogte van de totale score; die verandert maximaal met + of $-5 \%$ bij minimale of maximale klimaatuitgaven in pijler 2 .

Scenario's licht en zwaar eco-schema en kringlooplandbouw hebben hoogste klimaatscore De klimaatscore van de uitgaven van pijler 1 in het basisscenario van 0,54 is gelijk aan de score in 2016, omdat in het basisscenario van dezelfde verdeling van de nationale envelop voor pijler 1 over de inkomens- en eco-schematoeslagen wordt uitgegaan (tabel 3.8). De klimaatscores in het lichte eco-schemascenario, het zware eco-schemascenario en het kringlooplandbouwscenario zijn het hoogst en komen alle drie op zo'n 0,8 uit. Het blijkt dat de klimaatscore hoger worden naarmate het aandeel van de uitgaven aan eco-schematoeslagen in de envelop voor pijler 1 groter wordt. De klimaatscore zegt echter niets over het aantal ha met een eco-schema: in het basisscenario met de laagste 
klimaatscore wordt er op het totale landbouwareaal aan eco-schema gedaan; in het zware ecoschemascenario met de hoogste klimaatscore valt er 15\% van het areaal onder een eco-schema.

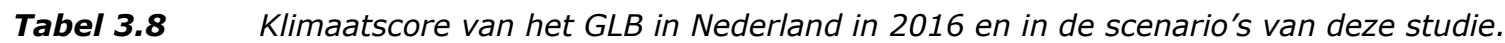

\begin{tabular}{|c|c|c|c|c|}
\hline & $\begin{array}{r}\text { Beschikbare } \\
\text { envelop pijler } 1 \\
(\mathrm{~m} \mid \mathrm{n} \text {. euro })\end{array}$ & $\begin{array}{r}\text { Uitgaven aan } \\
\text { inkomens- } \\
\text { toeslagen (mln. } \\
\text { euro) }\end{array}$ & $\begin{array}{r}\text { Uitgaven aan eco- } \\
\text { schema-toeslagen } \\
(\mathrm{m} / \mathrm{n} \text {. euro })\end{array}$ & Klimaatscore \\
\hline 2016 & 768 & 502 & 215 & 0,54 \\
\hline Basisscenario & 704 & 460 & 197 & 0,54 \\
\hline Basisplus-scenario & 704 & 329 & 329 & 0,65 \\
\hline Licht eco-schemascenario & 704 & 164 & 493 & 0,79 \\
\hline Zwaar eco-schemascenario & 598 & 110 & 441 & 0,81 \\
\hline Kringlooplandbouw-scenario & 598 & 138 & 414 & 0,78 \\
\hline
\end{tabular}

Bron: berekeningen Wageningen Economic Research. 


\section{$4 \quad$ Slotbeschouwing}

De wetgevende voorstellen voor het GLB voor de jaren 2021-2027 bieden lidstaten veel vrijheid bij de toekenning van toeslagen in de eerste pijler van het GLB. In deze studie zijn de gevolgen voor de omvang van de toeslagen van de eerste pijler en de inkomens op landbouwbedrijven in Nederland in vijf scenario's doorgerekend, uitgaand van uiteenlopende keuzes voor de invulling van de toeslagen van de eerste pijler. De scenario's schetsen de situatie in het jaar 2021. Ook zijn de veranderingen ten opzichte van 2020 aangegeven. Dit hoofdstuk zet de conclusies uiteen en geeft een beschouwing over de mogelijkheden voor de invulling van de eco-schema's in de verschillende scenario's.

Voor de berekeningen in deze studie zijn diverse aannames gemaakt, zoals de veronderstelling dat de bedrijfsgrootte niet verandert en er geen inflatie is. De verschillende aannames hebben tot gevolg dat de uitkomsten van deze studie moeten gezien worden als grove indicaties van de mogelijke effecten. De cijfers weerspiegelen een mogelijke bandbreedte. Het gaat daarbij ook enkel om de eerste orde inkomenseffecten van de toeslagen.

Toeslag per ha in basisscenario daalt met 4\% ten opzichte van 2020

In het basisscenario - voortzetting van de huidige implementatie van het GLB - krijgen alle boeren zowel een inkomenstoeslag als een eco-schematoeslag. Iedereen neemt deel aan een eco-schema dat vergelijkbaar is met de huidige vergroeningseisen. Elke boer ontvangt dan een inkomenstoeslag van 258 euro en een eco-schematoeslag van 111 euro per ha. De totale toeslag per ha van 369 euro is $4 \%$ lager dan de toeslag van 383 euro per ha in 2020. Dit is een direct gevolg van een kleinere nationale envelop voor toeslagen zoals voorgesteld in de voorstellen van de EC.

Hogere eco-schematoeslag in scenario's met geringere deelname aan eco-schema's In de vier overige scenario's gaat het aandeel van de envelop voor de eerste pijler dat aan inkomenstoeslagen wordt besteed omlaag en het aandeel van de envelop voor eco-schematoeslagen omhoog. Ook is de veronderstelling dat minder boeren deelnemen aan een eco-schema. De inkomenstoeslag per ha gaat daardoor omlaag en de eco-schematoeslag omhoog. De inkomenstoeslag varieert van 62 euro in het zware eco-schemascenario tot 184 euro in het basisplus-scenario. De ecoschematoeslag varieert van 205 euro per ha in het basisplusscenario tot 1.650 euro in het zware ecoschemascenario. In dit laatste scenario doet $15 \%$ van de boeren mee aan een eco-schema op 15\% van het landbouwareaal. Dit betekent ook dat op een aanzienlijk deel van het landbouwareaal geen extra inspanningen op het gebied van milieu, landschap en klimaat worden geleverd.

\section{Inkomen in basisscenario 1\% lager dan in 2020}

Voor alle bedrijven gemiddeld nemen de inkomens uit bedrijf (inclusief toeslagen) in het basisscenario met zo'n $1 \%$ af ten opzichte van de inkomens in 2020. Dit is minder dan de $4 \%$ afname van het budget voor toeslagen. De reden is dat de toeslagen maar een deel van het inkomen vormen. Voor bedrijven waar de toeslagen een groter deel van het inkomen vormen, is het inkomenseffect groter. Daarom is op de overige graasdierbedrijven, melkveebedrijven, zetmeelaardappelbedrijven, akkerbouwbedrijven en gemengde bedrijven de afname van het inkomen wat groter en op hokdierbedrijven, tuinbouwbedrijven en vleeskalverbedrijven kleiner.

De grootste veranderingen in het inkomen vinden plaats in de huidige implementatieperiode van het GLB (2014-2020) als gevolg van de convergentie van de toeslagen door de overstap van toeslagen op historische basis naar een flat rate.

Inkomens op bedrijven zonder eco-schema dalen met 10-20\%

In het basisplus-scenario loopt het inkomen uit bedrijf gemiddeld met ruim $10 \%$ terug op bedrijven die alleen een inkomenstoeslag ontvangen in vergelijking met het basisscenario. In de lichte en zware eco-schemascenario's en het kringlooplandbouwscenario dalen de inkomens uit bedrijf gemiddeld tot circa $80 \%$ van dat in het basisscenario. De reden is de beschikbare envelop voor inkomenstoeslagen, deze is veel kleiner dan in het basisscenario. De inkomens uit bedrijf op de akkerbouwbedrijven, 
zetmeelaardappelbedrijven, melkveebedrijven, overige graasdierbedrijven en gemengde bedrijven nemen bovengemiddeld af in de scenario's; dat heeft te maken met een relatief groot aantal ha op deze bedrijfstypen en een relatief hoog aandeel van de toeslagen in het inkomen.

Hoe groter het aandeel is van de nationale envelop dat wordt besteed aan eco-schema's, en hoe zwaarder de eisen voor deelname aan eco-schema's, hoe groter de inkomensgevolgen zullen zijn omdat naar verwachting minder boeren dan zullen deelnemen aan een eco-schema.

\section{Inkomens in scenario's kunnen door deelname aan eco-schema stijgen}

Het inkomen op bedrijven die aan een eco-schema deelnemen komt in het basisplusscenario $1 \%$ boven dat in het basisscenario uit; in het lichte eco-schemascenario is het inkomen $10 \%$ hoger vergeleken met het basisscenario. Daarbij zijn de eco-schematoeslagen volledig toegerekend als inkomen. Voor de andere drie scenario's is het inkomenseffect afhankelijk van de vraag welk deel van de toeslag als inkomen resteert. Ter illustratie, als $10 \%$ van de toeslag resteert als inkomen, stijgt het inkomen met enkele procenten in vergelijking met de situatie zonder eco-schematoeslag.

Mogelijke invulling van de eco-schema's in de scenario's

In het basisscenario nemen alle bedrijven deel aan een eco-schema, waarvan de voorwaarden gelijk zijn aan de huidige vergroeningsvoorwaarden. In de vier andere scenario's is een hogere eco-schematoeslag per ha beschikbaar van respectievelijke 205 euro in het basisplusscenario, 425 euro in het lichte ecoschemascenario, 580 euro in het kringlooplandbouwscenario en 1.650 euro in het zware ecoschemascenario. Gezien de hoogte van deze toeslagen kunnen strengere voorwaarden aan boeren worden gesteld dan in het basisscenario. Met behulp van de groenblauwe catalogus wordt in tabel 4.1 een indicatie gegeven aan welke maatregelen in elk scenario kan worden gedacht, uiteraard zijn andere invullingen ook mogelijk. Daarin spelen zowel de aard van het pakket als de toepasbaarheid op grasland of bouwland een rol. Dat leidt in het basisplus-scenario en het lichte eco-schemascenario tot pakketten die gedurende een beperkte periode van het jaar worden toegepast, in het zware eco-schema zitten ook pakketten die gepaard gaan met een aanzienlijke opbrengstderving en extensief grondgebruik; in het kringlooplandbouwscenario gaat het om pakketten gericht op het gebruik van dierlijke mest of op de teelt van bodemverbeterende gewassen. Net als met de huidige vergroeningsmaatregelen kunnen boeren kiezen uit verschillende pakketten. Bij het zware-eco-schemascenario kunnen boeren de pakketten uit het lichte eco-schemascenario aanvullen met een aantal zwaardere pakketten.

Tabel 4.1 Indicatie van mogelijke beheerpakketten a) in de eco-schema's van de scenario's

\begin{tabular}{|c|c|c|c|c|}
\hline & $\begin{array}{r}\text { Ecoschema-toeslag } \\
\text { (euro per ha) }\end{array}$ & Indicatie beheerpakket & Beheercode & $\begin{array}{r}\text { Vergoeding pakket } \\
\text { (euro per ha) }\end{array}$ \\
\hline \multicolumn{5}{|l|}{ Grasland } \\
\hline \multirow{2}{*}{ 2. Basisplus } & & Kuikenvelden & $2 a$ & 715 \\
\hline & & Plasdras & $3 n$ & 319 \\
\hline \multirow[t]{2}{*}{ 4. Zwaar eco-schema } & 1650 & Idem aan basisplus-scenario plus: & & \\
\hline & & Extensief beweid grasland & $6 \mathrm{~b}$ & 2.532 \\
\hline \multirow[t]{2}{*}{ 5. Kringlooplandbouw } & 580 & Kruidenrijk grasland & $5 a$ & 1.701 \\
\hline & & Ruige mest & $7 a$ & 270 \\
\hline 3.Licht eco-schema & 425 & Idem aan basisplus-scenario & & \\
\hline \multirow[t]{2}{*}{ 4.Zwaar eco-schema } & 1650 & Idem aan basisplus-scenario plus: & & \\
\hline & & Wintervoedselakker & $15 a-c$ & 2512 \\
\hline \multirow[t]{3}{*}{ 5.Kringlooplandbouw } & 580 & Vogelakker & $16 a-c$ & 3290 \\
\hline & & Bouwland voor hamsters & $17 a$ & 3022 \\
\hline & & Kruidenrijke akker & $18 a-e$ & 2572 \\
\hline
\end{tabular}

a) Zie bijlage 2 voor een korte beschrijving van de beheerpakketten.

Bron: Vergoedingen per pakket komen uit Bijlage 4SVNLbeheerjaar2018-activiteitentabel2018\% bij de Model Subsidieverordening Natuur- en Landschapsbeheer (SVNL) - beheerjaar 2018, via www.bij12.nl. 
Uit tabel 4.1 blijkt dat de vergoedingen per ha uit de pakketten over het algemeen hoger zijn dan de beschikbare eco-schematoeslag in de scenario's. Boeren kunnen dus maar een deel van hun landbouwareaal onder een pakket laten vallen, wat vergelijkbaar is met de huidige vergroeningsmaatregelen. Zo kan bijvoorbeeld worden gedacht aan een invulling van het eco-schema in het basisplus-scenario met de verplichting om 27\% (205/752) van het grasland op het bedrijf onder het pakket grasland met een rustperiode te laten vallen of kruidenrijke akkerranden aan te leggen op bouwland met een totale oppervlakte van 6\% (205/3290) van het landbouwareaal op het bedrijf. In het lichte eco-schema kunnen deze percentages worden verhoogd tot respectievelijk 54\% (425/752) en $13 \%$ (425/3290). Het zware eco-schema zou kunnen bestaan uit een stapeling van een plasdraspakket op $100 \%$ (319/319) van het areaal en een pakket extensief beweid grasland op 53\% ((1650$319) / 2532)$ van het grasland op het bedrijf of uit een kruidenrijke akkerrand op $10 \%(329 / 3290)$ van het areaal en een wintervoedselakker op 53\% ((1650-329)/2512) van het areaal op bedrijven met bouwland. Het eco-schema voor de kringlooplandbouw zou kunnen worden ingevuld met een verplichting om 34\% (580/1701) van het grasland onder een kruidenrijk graslandpakket of $23 \%$ $(580 / 2572)$ van het bouwland onder een kruidenrijk akkerpakket te laten vallen. 


\section{$5 \quad$ Literatuur}

EC (Europese Commissie) (2017). De toekomst van voeding en landbouw. Mededeling van de Commissie aan het Europees Parlement, de Raad, het Europees Economisch en Sociaal Comité en

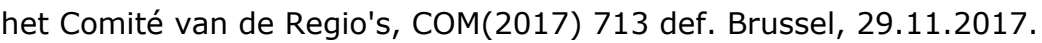

EC (2018a). Regulation of the European Parliament and of the Council establishing rules on support for strategic plans to be drawn up by Member States under the Common agricultural policy (CAP Strategic Plans) and financed by the European Agricultural Guarantee Fund (EAGF) and by the European Agricultural Fund for Rural Development (EAFRD) and repealing Regulation (EU) No $1305 / 2013$ of the European Parliament and of the Council and Regulation (EU) No 1307/2013 of the European Parliament and of the Council. COM(2018) 392 final. Brussel, 1.6.2018.

EC (2018b). EU-begroting: het GLB na 2020. Brussel, factsheet, via website: https://ec.europa.eu/commission/sites/beta-political/files/budget-may2018-modernisingcap_nl_0.pdf.

Jongeneel, R., C.J.A.M de Bont, J.H. Jager, H. Prins, P. Roza en A.B. Smit (2011). Bedrijfstoeslagen na 2013; omgaan met dalende bedragen. Den Haag, LEI-WUR, Rapportnr. 2011-062.

Maas, J. en A. Thijssen (red.) (2018). Technische Briefing Kringlooplandbouw: Wat mogen we verwachten van een circulaire voedselproductie gebaseerd op een kringlooplandbouw, in het perspectief van klimaat- en biodiversiteitdoelen? Wageningen, Wageningen University \& Research. Notitie opgesteld op verzoek van de Tweede Kamer Commissie LNV.

Meulen, H.A.B. van der, A.B. Smit en J.H. Jager (2017). Effecten nieuw GLB op inkomens, kosten en administratieve lasten; Gevolgen van aanpassing directe betalingen en invoering vergroeningseisen. Wageningen, Wageningen Economic Research, Rapport 2017-080.

Terluin, I.J., J.H. Jager en R.A. Jongeneel (2014). Convergentie toeslagen Eerste Pijler GLB in Nederland, 2014-2019. Wageningen, LEI Wageningen UR (University \& Research Centre), LEIRapport 2014-001. 


\section{Bijlage 1 Inkomen uit bedrijf in de vijf scenario's voor geselecteerde bedrijfstypen}

Tabel B3.1 Inkomen uit bedrijf in de verschillende scenario's: alle bedrijven, 2021.

\begin{tabular}{|c|c|c|c|c|c|c|c|c|}
\hline Scenario & & 1 & & & 2 & 3 & 4 & 5 \\
\hline \multirow[t]{9}{*}{$\begin{array}{l}\text { Alle } \\
\text { bedrijven }\end{array}$} & $\begin{array}{l}\text { Toeslagen eerste } \\
\text { pijler, } 2021 \text { (euro) }\end{array}$ & 14.324 & \multirow{4}{*}{$\begin{array}{l}\text { Bedrijven met } \\
\text { alleen een } \\
\text { inkomenstoeslag }\end{array}$} & $\begin{array}{l}\text { Toeslagen eerste } \\
\text { pijler, } 2021 \\
\text { (euro) }\end{array}$ & 7.162 & 3.581 & 2.405 & 3.006 \\
\hline & $\begin{array}{l}\text { Inkomen uit } \\
\text { bedrijf, } 2021 \\
\text { (euro) }\end{array}$ & 60.124 & & $\begin{array}{l}\text { Inkomen uit } \\
\text { bedrijf, } 2021 \\
\text { (euro) }\end{array}$ & 52.962 & 49.381 & 48.205 & 48.806 \\
\hline & $\begin{array}{l}\text { Inkomen uit } \\
\text { bedrijf, } 2021 \\
\text { (index, inkomen } \\
\text { in scenario } 1= \\
100 \text { ) }\end{array}$ & 100 & & $\begin{array}{l}\text { Inkomen uit } \\
\text { bedrijf, } 2021 \\
\text { (index, inkomen } \\
\text { in scenario } 1= \\
100 \text { ) }\end{array}$ & 88 & 82 & 80 & 81 \\
\hline & $\begin{array}{l}\text { Toeslagen eerste } \\
\text { pijler als\% } \\
\text { inkomen, } 2021\end{array}$ & 24 & & $\begin{array}{l}\text { Toeslagen eerste } \\
\text { pijler als\% } \\
\text { inkomen, } 2021\end{array}$ & 14 & 7 & 5 & 6 \\
\hline & & & \multirow{4}{*}{$\begin{array}{l}\text { Bedrijven met een } \\
\text { inkomenstoeslag } \\
\text { en een } \\
\text { vergroenings- } \\
\text { toeslag }\end{array}$} & $\begin{array}{l}\text { Toeslagen eerste } \\
\text { pijler, } 2021 \\
\text { (euro) }\end{array}$ & 15.119 & 20.108 & 66.526 & 25.548 \\
\hline & & & & $\begin{array}{l}\text { Inkomen uit } \\
\text { bedrijf, } 2021 \\
\text { (euro) }\end{array}$ & 60.919 & 65.908 & 112.326 & 71.348 \\
\hline & & & & $\begin{array}{l}\text { Inkomen uit } \\
\text { bedrijf, } 2021 \\
\text { (index, inkomen } \\
\text { in scenario } 1= \\
100 \text { ) }\end{array}$ & 101 & 110 & 187 & 119 \\
\hline & & & & $\begin{array}{l}\text { Toeslagen eerste } \\
\text { pijler als\% } \\
\text { inkomen, } 2021\end{array}$ & 25 & 31 & 59 & 36 \\
\hline & $\begin{array}{l}\text { Aantal ha met } \\
\text { vergroenings- } \\
\text { toeslag }(* 1.000)\end{array}$ & 1.784 & & & 1.606 & 1.160 & 268 & 714 \\
\hline
\end{tabular}


Tabel B3.2 Inkomen uit bedrijf in de verschillende scenario's: akkerbouwbedrijven, 2021.

\begin{tabular}{|c|c|c|c|c|c|c|c|c|}
\hline Scenario & & 1 & & & 2 & 3 & 4 & 5 \\
\hline \multirow[t]{9}{*}{$\begin{array}{l}\text { Alle } \\
\text { bedrijven }\end{array}$} & $\begin{array}{l}\text { Toeslagen eerste } \\
\text { pijler, } 2021 \\
\text { (euro) }\end{array}$ & 21.259 & \multirow[t]{4}{*}{$\begin{array}{l}\text { Bedrijven met } \\
\text { alleen een } \\
\text { inkomenstoeslag }\end{array}$} & $\begin{array}{l}\text { Toeslagen eerste } \\
\text { pijler, } 2021 \\
\text { (euro) }\end{array}$ & 10.629 & 5.315 & 3.569 & 4.461 \\
\hline & $\begin{array}{l}\text { Inkomen uit } \\
\text { bedrijf, } 2021 \\
\text { (euro) }\end{array}$ & 58.629 & & $\begin{array}{l}\text { Inkomen uit } \\
\text { bedrijf, } 2021 \\
\text { (euro) }\end{array}$ & 47.999 & 42.685 & 40.939 & 41.831 \\
\hline & $\begin{array}{l}\text { Inkomen uit } \\
\text { bedrijf, } 2021 \\
\text { (index, inkomen } \\
\text { in scenario } 1= \\
100 \text { ) }\end{array}$ & 100 & & $\begin{array}{l}\text { Inkomen uit } \\
\text { bedrijf, } 2021 \\
\text { (index, inkomen } \\
\text { in scenario } 1= \\
100 \text { ) }\end{array}$ & 82 & 73 & 70 & 71 \\
\hline & $\begin{array}{l}\text { Toeslagen eerste } \\
\text { pijler als\% } \\
\text { inkomen, } 2021\end{array}$ & 36 & & $\begin{array}{l}\text { Toeslagen eerste } \\
\text { pijler als\% } \\
\text { inkomen, } 2021\end{array}$ & 22 & 12 & 9 & 11 \\
\hline & & & \multirow{4}{*}{$\begin{array}{l}\text { Bedrijven met een } \\
\text { inkomenstoeslag } \\
\text { en een } \\
\text { vergroenings- } \\
\text { toeslag }\end{array}$} & $\begin{array}{l}\text { Toeslagen eerste } \\
\text { pijler, } 2021 \\
\text { (euro) }\end{array}$ & 22.440 & 29.844 & 98.736 & 37.918 \\
\hline & & & & $\begin{array}{l}\text { Inkomen uit } \\
\text { bedrijf, } 2021 \\
\text { (euro) }\end{array}$ & 59.810 & 67.214 & 136.106 & 75.288 \\
\hline & & & & $\begin{array}{l}\text { Inkomen uit } \\
\text { bedrijf, } 2021 \\
\text { (index, inkomen } \\
\text { in scenario } 1= \\
100 \text { ) }\end{array}$ & 102 & 115 & 232 & 128 \\
\hline & & & & $\begin{array}{l}\text { Toeslagen eerste } \\
\text { pijler als\% } \\
\text { inkomen, } 2021\end{array}$ & 38 & 44 & 73 & 50 \\
\hline & $\begin{array}{l}\text { Aantal ha met } \\
\text { vergroenings- } \\
\text { toeslag }(* 1.000)\end{array}$ & 378 & & & 340 & 246 & 57 & 151 \\
\hline
\end{tabular}


Tabel B3.3 Inkomen uit bedrijf in de verschillende scenario's: zetmeelaardappelbedrijven, 2021.

\begin{tabular}{|c|c|c|c|c|c|c|c|c|}
\hline Scenario & & 1 & & & 2 & 3 & 4 & 5 \\
\hline \multirow[t]{9}{*}{$\begin{array}{l}\text { Alle } \\
\text { bedrijven }\end{array}$} & $\begin{array}{l}\text { Toeslagen eerste } \\
\text { pijler, } 2021 \text { (euro) }\end{array}$ & 29.952 & \multirow[t]{4}{*}{$\begin{array}{l}\text { Bedrijven met } \\
\text { alleen een } \\
\text { inkomenstoeslag }\end{array}$} & $\begin{array}{l}\text { Toeslagen eerste } \\
\text { pijler, } 2021 \\
\text { (euro) }\end{array}$ & 14.976 & 7.488 & 5.028 & 6.285 \\
\hline & $\begin{array}{l}\text { Inkomen uit } \\
\text { bedrijf, } 2021 \\
\text { (euro) }\end{array}$ & 66.912 & & $\begin{array}{l}\text { Inkomen uit } \\
\text { bedrijf, } 2021 \\
\text { (euro) }\end{array}$ & 51.936 & 44.448 & 41.988 & 43.245 \\
\hline & $\begin{array}{l}\text { Inkomen uit } \\
\text { bedrijf, } 2021 \\
\text { (index, inkomen } \\
\text { in scenario } 1= \\
100 \text { ) }\end{array}$ & 100 & & $\begin{array}{l}\text { Inkomen uit } \\
\text { bedrijf, } 2021 \\
\text { (index, inkomen } \\
\text { in scenario } 1= \\
100 \text { ) }\end{array}$ & 78 & 66 & 63 & 65 \\
\hline & $\begin{array}{l}\text { Toeslagen eerste } \\
\text { pijler als\% } \\
\text { inkomen, } 2021\end{array}$ & 45 & & $\begin{array}{l}\text { Toeslagen eerste } \\
\text { pijler als\% } \\
\text { inkomen, } 2021\end{array}$ & 29 & 17 & 12 & 15 \\
\hline & & & \multirow{4}{*}{$\begin{array}{l}\text { Bedrijven met een } \\
\text { inkomenstoeslag } \\
\text { en een } \\
\text { vergroenings- } \\
\text { toeslag }\end{array}$} & $\begin{array}{l}\text { Toeslagen eerste } \\
\text { pijler, } 2021 \\
\text { (euro) }\end{array}$ & 31.616 & 42.048 & 139.110 & 53.423 \\
\hline & & & & $\begin{array}{l}\text { Inkomen uit } \\
\text { bedrijf, } 2021 \\
\text { (euro) }\end{array}$ & 68.576 & 79.008 & 176.070 & 90.383 \\
\hline & & & & $\begin{array}{l}\text { Inkomen uit } \\
\text { bedrijf, } 2021 \\
\text { (index, inkomen } \\
\text { in scenario } 1= \\
100 \text { ) }\end{array}$ & 102 & 118 & 263 & 135 \\
\hline & & & & $\begin{array}{l}\text { Toeslagen eerste } \\
\text { pijler als\% } \\
\text { inkomen, } 2021\end{array}$ & 46 & 53 & 79 & 59 \\
\hline & $\begin{array}{l}\text { Aantal ha met } \\
\text { vergroenings- } \\
\text { toeslag }(* 1000)\end{array}$ & 63 & & & 57 & 41 & 10 & 25 \\
\hline
\end{tabular}


Tabel B3.4 Inkomen uit bedrijf in de verschillende scenario's: melkveebedrijven, 2021.

\begin{tabular}{|c|c|c|c|c|c|c|c|c|}
\hline Scenario & & 1 & & & 2 & 3 & 4 & 5 \\
\hline \multirow[t]{9}{*}{$\begin{array}{l}\text { Alle } \\
\text { bedrijven }\end{array}$} & $\begin{array}{l}\text { Toeslagen eerste } \\
\text { pijler, } 2021 \text { (euro) }\end{array}$ & 20.312 & \multirow{4}{*}{$\begin{array}{l}\text { Bedrijven met } \\
\text { alleen een } \\
\text { inkomenstoeslag }\end{array}$} & $\begin{array}{l}\text { Toeslagen eerste } \\
\text { pijler, } 2021 \text { (euro) }\end{array}$ & 10.156 & 5.078 & 3.410 & 4.262 \\
\hline & $\begin{array}{l}\text { Inkomen uit } \\
\text { bedrijf, } 2021 \\
\text { (euro) }\end{array}$ & 40.792 & & $\begin{array}{l}\text { Inkomen uit bedrijf, } \\
2021 \text { (euro) }\end{array}$ & 30.636 & 25.558 & 23.890 & 24.742 \\
\hline & $\begin{array}{l}\text { Inkomen uit } \\
\text { bedrijf, } 2021 \\
\text { (index, inkomen } \\
\text { in scenario } 1= \\
100 \text { ) }\end{array}$ & 100 & & $\begin{array}{l}\text { Inkomen uit bedrijf, } \\
2021 \text { (index, } \\
\text { inkomen in scenario } \\
1=100 \text { ) }\end{array}$ & 75 & 63 & 59 & 61 \\
\hline & $\begin{array}{l}\text { Toeslagen eerste } \\
\text { pijler als\% } \\
\text { inkomen, } 2021\end{array}$ & 50 & & $\begin{array}{l}\text { Toeslagen eerste } \\
\text { pijler als\% inkomen, } \\
2021\end{array}$ & 33 & 20 & 14 & 17 \\
\hline & & & \multirow{5}{*}{$\begin{array}{l}\text { Bedrijven met } \\
\text { een } \\
\text { inkomenstoeslag } \\
\text { en een } \\
\text { vergroenings- } \\
\text { toeslag }\end{array}$} & $\begin{array}{l}\text { Toeslagen eerste } \\
\text { pijler, } 2021 \text { (euro) }\end{array}$ & 21.440 & 28.515 & 94.337 & 36.229 \\
\hline & & & & $\begin{array}{l}\text { Inkomen uit bedrijf, } \\
2021 \text { (euro) }\end{array}$ & 41.920 & 48.995 & 114.817 & 56.709 \\
\hline & & & & $\begin{array}{l}\text { Inkomen uit bedrijf, } \\
2021 \text { (index, } \\
\text { inkomen in scenario } \\
1=100 \text { ) }\end{array}$ & 103 & 120 & 281 & 139 \\
\hline & & & & $\begin{array}{l}\text { Toeslagen eerste } \\
\text { pijler als\% inkomen, } \\
2021\end{array}$ & 51 & 58 & 82 & 64 \\
\hline & $\begin{array}{l}\text { Aantal ha met } \\
\text { vergroenings- } \\
\text { toeslag }(* 1.000)\end{array}$ & 906 & & & 815 & 589 & 136 & 362 \\
\hline
\end{tabular}


Tabel B3.5 Inkomen uit bedrijf in de verschillende scenario's: vleeskalverbedrijven, 2021.

\begin{tabular}{|c|c|c|c|c|c|c|c|c|}
\hline Scenario & & 1 & & & 2 & 3 & 4 & 5 \\
\hline \multirow[t]{9}{*}{$\begin{array}{l}\text { Alle } \\
\text { bedrijven }\end{array}$} & $\begin{array}{l}\text { Toeslagen eerste } \\
\text { pijler, } 2021 \text { (euro) }\end{array}$ & 3.018 & \multirow{4}{*}{$\begin{array}{l}\text { Bedrijven met } \\
\text { alleen een } \\
\text { inkomenstoesla } \\
\mathrm{g}\end{array}$} & $\begin{array}{l}\text { Toeslagen eerste } \\
\text { pijler, } 2021 \text { (euro) }\end{array}$ & 1.509 & 755 & 507 & 633 \\
\hline & $\begin{array}{l}\text { Inkomen uit } \\
\text { bedrijf, } 2021 \\
\text { (euro) }\end{array}$ & 32.708 & & $\begin{array}{l}\text { Inkomen uit bedrijf, } \\
2021 \text { (euro) }\end{array}$ & 31.199 & 30.445 & 30.197 & 30.323 \\
\hline & $\begin{array}{l}\text { Inkomen uit } \\
\text { bedrijf, } 2021 \\
\text { (index, inkomen } \\
\text { in scenario } 1 \text { = } \\
100 \text { ) }\end{array}$ & 100 & & $\begin{array}{l}\text { Inkomen uit bedrijf, } \\
2021 \text { (index, } \\
\text { inkomen in scenario } \\
1=100 \text { ) }\end{array}$ & 95 & 93 & 92 & 93 \\
\hline & $\begin{array}{l}\text { Toeslagen eerste } \\
\text { pijler als\% } \\
\text { inkomen, } 2021\end{array}$ & 9 & & $\begin{array}{l}\text { Toeslagen eerste } \\
\text { pijler als\% } \\
\text { inkomen, } 2021\end{array}$ & 5 & 2 & 2 & 2 \\
\hline & & & \multirow{5}{*}{$\begin{array}{l}\text { Bedrijven met } \\
\text { een } \\
\text { inkomenstoesla } \\
\text { g en een } \\
\text { vergroenings- } \\
\text { toeslag }\end{array}$} & $\begin{array}{l}\text { Toeslagen eerste } \\
\text { pijler, } 2021 \text { (euro) }\end{array}$ & 3.186 & 4.237 & 14.017 & 5.383 \\
\hline & & & & $\begin{array}{l}\text { Inkomen uit bedrijf, } \\
2021 \text { (euro) }\end{array}$ & 32.876 & 33.927 & 43.707 & 35.073 \\
\hline & & & & $\begin{array}{l}\text { Inkomen uit bedrijf, } \\
2021 \text { (index, } \\
\text { inkomen in scenario } \\
1=100 \text { ) }\end{array}$ & 101 & 104 & 134 & 107 \\
\hline & & & & $\begin{array}{l}\text { Toeslagen eerste } \\
\text { pijler als\% } \\
\text { inkomen, } 2021\end{array}$ & 10 & 12 & 32 & 15 \\
\hline & $\begin{array}{l}\text { Aantal ha met } \\
\text { vergroenings- } \\
\text { toeslag }(* 1.000)\end{array}$ & 6 & & & 5 & 4 & 1 & 2 \\
\hline
\end{tabular}


Tabel B3.6 Inkomen uit bedrijf in de verschillende scenario's: overige graasdierbedrijven, 2021.

\begin{tabular}{|c|c|c|c|c|c|c|c|c|}
\hline Scenario & & 1 & & & 2 & 3 & 4 & 5 \\
\hline \multirow[t]{9}{*}{$\begin{array}{l}\text { Alle } \\
\text { bedrijven }\end{array}$} & $\begin{array}{l}\text { Toeslagen eerste } \\
\text { pijler, } 2021 \text { (euro) }\end{array}$ & 8.170 & \multirow{4}{*}{$\begin{array}{l}\text { Bedrijven met } \\
\text { alleen een } \\
\text { inkomenstoeslag }\end{array}$} & $\begin{array}{l}\text { Toeslagen eerste } \\
\text { pijler, } 2021 \text { (euro) }\end{array}$ & 4.085 & 2.042 & 1.371 & 1.714 \\
\hline & $\begin{array}{l}\text { Inkomen uit } \\
\text { bedrijf, } 2021 \\
\text { (euro) }\end{array}$ & -3.230 & & $\begin{array}{l}\text { Inkomen uit bedrijf, } \\
2021 \text { (euro) }\end{array}$ & -7.315 & -9.358 & -10.029 & -9.686 \\
\hline & $\begin{array}{l}\text { Inkomen uit } \\
\text { bedrijf, } 2021 \\
\text { (index, inkomen } \\
\text { in scenario } 1= \\
100 \text { ) }\end{array}$ & 100 & & $\begin{array}{l}\text { Inkomen uit bedrijf, } \\
2021 \text { (index, } \\
\text { inkomen in scenario } \\
1=100 \text { ) }\end{array}$ & 226 & 290 & 310 & 300 \\
\hline & $\begin{array}{l}\text { Toeslagen eerste } \\
\text { pijler als\% } \\
\text { inkomen, } 2021\end{array}$ & -253 & & $\begin{array}{l}\text { Toeslagen eerste } \\
\text { pijler als\% } \\
\text { inkomen, } 2021\end{array}$ & -56 & -22 & -14 & -18 \\
\hline & & & \multirow{5}{*}{$\begin{array}{l}\text { Bedrijven met een } \\
\text { inkomenstoeslag } \\
\text { en een } \\
\text { vergroenings- } \\
\text { toeslag }\end{array}$} & $\begin{array}{l}\text { Toeslagen eerste } \\
\text { pijler, } 2021 \text { (euro) }\end{array}$ & 8.624 & 11.469 & 37.944 & 14.572 \\
\hline & & & & $\begin{array}{l}\text { Inkomen uit bedrijf, } \\
2021 \text { (euro) }\end{array}$ & -2.776 & 69 & 26.544 & 3.172 \\
\hline & & & & $\begin{array}{l}\text { Inkomen uit bedrijf, } \\
2021 \text { (index, } \\
\text { inkomen in scenario } \\
1=100 \text { ) }\end{array}$ & 86 & -2 & -822 & -98 \\
\hline & & & & $\begin{array}{l}\text { Toeslagen eerste } \\
\text { pijler als\% } \\
\text { inkomen, } 2021\end{array}$ & -311 & 16.640 & 143 & 459 \\
\hline & $\begin{array}{l}\text { Aantal ha met } \\
\text { vergroenings- } \\
\text { toeslag }(* 1.000)\end{array}$ & 121 & & & 109 & 79 & 18 & 48 \\
\hline
\end{tabular}


Tabel B3.7 Inkomen uit bedrijf in de verschillende scenario's: hokdierbedrijven, 2021.

\begin{tabular}{|c|c|c|c|c|c|c|c|c|}
\hline Scenario & & 1 & & & 2 & 3 & 4 & 5 \\
\hline \multirow[t]{9}{*}{$\begin{array}{l}\text { Alle } \\
\text { bedrijven }\end{array}$} & $\begin{array}{l}\text { Toeslagen eerste } \\
\text { pijler, } 2021 \text { (euro) }\end{array}$ & 3.059 & \multirow{4}{*}{$\begin{array}{l}\text { Bedrijven met } \\
\text { alleen een } \\
\text { inkomenstoeslag }\end{array}$} & $\begin{array}{l}\text { Toeslagen eerste } \\
\text { pijler, } 2021 \\
\text { (euro) }\end{array}$ & 1.529 & 765 & 513 & 642 \\
\hline & $\begin{array}{l}\text { Inkomen uit } \\
\text { bedrijf, } 2021 \\
\text { (euro) }\end{array}$ & 53.319 & & $\begin{array}{l}\text { Inkomen uit } \\
\text { bedrijf, } 2021 \\
\text { (euro) }\end{array}$ & 51.789 & 51.025 & 50.773 & 50.902 \\
\hline & $\begin{array}{l}\text { Inkomen uit } \\
\text { bedrijf, } 2021 \\
\text { (index, inkomen } \\
\text { in scenario } 1= \\
100 \text { ) }\end{array}$ & 100 & & $\begin{array}{l}\text { Inkomen uit } \\
\text { bedrijf, } 2021 \\
\text { (index, inkomen } \\
\text { in scenario } 1= \\
100 \text { ) }\end{array}$ & 97 & 96 & 95 & 95 \\
\hline & $\begin{array}{l}\text { Toeslagen eerste } \\
\text { pijler als\% } \\
\text { inkomen, } 2021\end{array}$ & 6 & & $\begin{array}{l}\text { Toeslagen eerste } \\
\text { pijler als\% } \\
\text { inkomen, } 2021\end{array}$ & 3 & 1 & 1 & 1 \\
\hline & & & \multirow{4}{*}{$\begin{array}{l}\text { Bedrijven met een } \\
\text { inkomenstoeslag } \\
\text { en een } \\
\text { vergroenings- } \\
\text { toeslag }\end{array}$} & $\begin{array}{l}\text { Toeslagen eerste } \\
\text { pijler, } 2021 \\
\text { (euro) }\end{array}$ & 3.228 & 4.294 & 14.205 & 5.455 \\
\hline & & & & $\begin{array}{l}\text { Inkomen uit } \\
\text { bedrijf, } 2021 \\
\text { (euro) }\end{array}$ & 53.488 & 54.554 & 64.465 & 55.715 \\
\hline & & & & $\begin{array}{l}\text { Inkomen uit } \\
\text { bedrijf, } 2021 \\
\text { (index, inkomen } \\
\text { in scenario } 1= \\
100 \text { ) }\end{array}$ & 100 & 102 & 121 & 104 \\
\hline & & & & $\begin{array}{l}\text { Toeslagen eerste } \\
\text { pijler als\% } \\
\text { inkomen, } 2021\end{array}$ & 6 & 8 & 22 & 10 \\
\hline & $\begin{array}{l}\text { Aantal ha met } \\
\text { vergroenings- } \\
\text { toeslag }(* 1.000)\end{array}$ & 35 & & & 31 & 22 & 5 & 14 \\
\hline
\end{tabular}


Tabel B3.8 Inkomen uit bedrijf in de verschillende scenario's: tuinbouwbedrijven, 2021.

\begin{tabular}{|c|c|c|c|c|c|c|c|c|}
\hline Scenario & & 1 & & & 2 & 3 & 4 & 5 \\
\hline \multirow[t]{9}{*}{$\begin{array}{l}\text { Alle } \\
\text { bedrijven }\end{array}$} & $\begin{array}{l}\text { Toeslagen eerste } \\
\text { pijler, } 2021 \text { (euro) }\end{array}$ & 5.929 & \multirow{4}{*}{$\begin{array}{l}\text { Bedrijven met } \\
\text { alleen een } \\
\text { inkomenstoeslag }\end{array}$} & $\begin{array}{l}\text { Toeslagen eerste } \\
\text { pijler, } 2021 \\
\text { (euro) }\end{array}$ & 2.965 & 1.482 & 995 & 1.244 \\
\hline & $\begin{array}{l}\text { Inkomen uit } \\
\text { bedrijf, } 2021 \\
\text { (euro) }\end{array}$ & 149.909 & & $\begin{array}{l}\text { Inkomen uit } \\
\text { bedrijf, } 2021 \\
\text { (euro) }\end{array}$ & 146.945 & 145.462 & 144.975 & 145.224 \\
\hline & $\begin{array}{l}\text { Inkomen uit } \\
\text { bedrijf, } 2021 \\
\text { (index, inkomen } \\
\text { in scenario } 1= \\
100 \text { ) }\end{array}$ & 100 & & $\begin{array}{l}\text { Inkomen uit } \\
\text { bedrijf, } 2021 \\
\text { (index, inkomen } \\
\text { in scenario } 1= \\
100 \text { ) }\end{array}$ & 98 & 97 & 97 & 97 \\
\hline & $\begin{array}{l}\text { Toeslagen eerste } \\
\text { pijler als\% } \\
\text { inkomen, } 2021\end{array}$ & 4 & & $\begin{array}{l}\text { Toeslagen eerste } \\
\text { pijler als\% } \\
\text { inkomen, } 2021\end{array}$ & 2 & 1 & 1 & 1 \\
\hline & & & \multirow{4}{*}{$\begin{array}{l}\text { Bedrijven met een } \\
\text { inkomenstoeslag } \\
\text { en een } \\
\text { vergroenings- } \\
\text { toeslag }\end{array}$} & $\begin{array}{l}\text { Toeslagen eerste } \\
\text { pijler, } 2021 \\
\text { (euro) }\end{array}$ & 6.259 & 8.324 & 27.538 & 10.576 \\
\hline & & & & $\begin{array}{l}\text { Inkomen uit } \\
\text { bedrijf, } 2021 \\
\text { (euro) }\end{array}$ & 150.239 & 152.304 & 171.518 & 154.556 \\
\hline & & & & $\begin{array}{l}\text { Inkomen uit } \\
\text { bedrijf, } 2021 \\
\text { (index, inkomen } \\
\text { in scenario } 1= \\
100 \text { ) }\end{array}$ & 100 & 102 & 114 & 103 \\
\hline & & & & $\begin{array}{l}\text { Toeslagen eerste } \\
\text { pijler als\% } \\
\text { inkomen, } 2021\end{array}$ & 4 & 5 & 16 & 7 \\
\hline & $\begin{array}{l}\text { Aantal ha met } \\
\text { vergroenings- } \\
\text { toeslag }(* 1.000)\end{array}$ & 134 & & & 121 & 87 & 20 & 54 \\
\hline
\end{tabular}


Tabel B3.9 Inkomen uit bedrijf in de verschillende scenario's: gemengde bedrijven, 2021.

\begin{tabular}{|c|c|c|c|c|c|c|c|c|}
\hline Scenario & & 1 & & & 2 & 3 & 4 & 5 \\
\hline \multirow[t]{9}{*}{ Alle bedrijven } & $\begin{array}{l}\text { Toeslagen eerste } \\
\text { pijler, } 2021 \\
\text { (euro) }\end{array}$ & 15.904 & \multirow[t]{4}{*}{$\begin{array}{l}\text { Bedrijven met } \\
\text { alleen een } \\
\text { inkomenstoeslag }\end{array}$} & $\begin{array}{l}\text { Toeslagen eerste } \\
\text { pijler, } 2021 \text { (euro) }\end{array}$ & 7.952 & 3.976 & 2.670 & 3.337 \\
\hline & $\begin{array}{l}\text { Inkomen uit } \\
\text { bedrijf, } 2021 \\
\text { (euro) }\end{array}$ & 49.724 & & $\begin{array}{l}\text { Inkomen uit } \\
\text { bedrijf, } 2021 \\
\text { (euro) }\end{array}$ & 41.772 & 37.796 & 36.490 & 37.157 \\
\hline & $\begin{array}{l}\text { Inkomen uit } \\
\text { bedrijf, } 2021 \\
\text { (index, inkomen } \\
\text { in scenario } 1= \\
100 \text { ) }\end{array}$ & 100 & & $\begin{array}{l}\text { Inkomen uit } \\
\text { bedrijf, } 2021 \\
\text { (index, inkomen } \\
\text { in scenario } 1= \\
100 \text { ) }\end{array}$ & 84 & 76 & 73 & 75 \\
\hline & $\begin{array}{l}\text { Toeslagen eerste } \\
\text { pijler als\% } \\
\text { inkomen, } 2021\end{array}$ & 32 & & $\begin{array}{l}\text { Toeslagen eerste } \\
\text { pijler als\% } \\
\text { inkomen, } 2021\end{array}$ & 19 & 11 & 7 & 9 \\
\hline & & & \multirow{5}{*}{$\begin{array}{l}\text { Bedrijven met een } \\
\text { inkomenstoeslag } \\
\text { en een } \\
\text { vergroenings- } \\
\text { toeslag }\end{array}$} & $\begin{array}{l}\text { Toeslagen eerste } \\
\text { pijler, } 2021 \text { (euro) }\end{array}$ & 16.788 & 22.327 & 73.868 & 28.368 \\
\hline & & & & $\begin{array}{l}\text { Inkomen uit } \\
\text { bedrijf, } 2021 \\
\text { (euro) }\end{array}$ & 50.608 & 56.147 & 107.688 & 62.188 \\
\hline & & & & $\begin{array}{l}\text { Inkomen uit } \\
\text { bedrijf, } 2021 \\
\text { (index, inkomen } \\
\text { in scenario } 1= \\
100 \text { ) }\end{array}$ & 102 & 113 & 217 & 125 \\
\hline & & & & $\begin{array}{l}\text { Toeslagen eerste } \\
\text { pijler als\% } \\
\text { inkomen, } 2021\end{array}$ & 33 & 40 & 69 & 46 \\
\hline & $\begin{array}{l}\text { Aantal ha met } \\
\text { vergroenings- } \\
\text { toeslag }(* 1.000)\end{array}$ & 127 & & & 115 & 83 & 19 & 51 \\
\hline
\end{tabular}




\section{Bijlage 2 Omschrijving van de beheerpakketten in de eco- schema's}

\begin{tabular}{|c|c|c|}
\hline Beheerpakket & $\begin{array}{l}\text { Beheer } \\
\text { code }\end{array}$ & Omschrijving \\
\hline Grasland met rustperiode & $1 a$ & $\begin{array}{l}\text { Er wordt een rustperiode in acht genomen van } 1 \text { april tot } 1 \text { juni } \\
\text { In de rustperiode vinden in de oppervlakte geen bewerkingen plaats } \\
\text { Beweiding is in de rustperiode niet toegestaan }\end{array}$ \\
\hline Kuikenvelden & $2 a$ & $\begin{array}{l}\text { Er wordt een rustperiode in acht genomen van twee weken in de } \\
\text { periode } 1 \text { mei tot } 1 \text { augustus } \\
\text { In de rustperiode vinden in de beheereenheid geen bewerkingen } \\
\text { plaats } \\
\text { Kuikenvelden mogen op zijn vroegst op } 1 \text { juni worden gemaaid }\end{array}$ \\
\hline Plasdras & $3 n$ & $\begin{array}{l}\text { De oppervlakte is gedurende tenminste twee weken in de } \\
\text { inundatieperiode - die loopt van } 1 \text { november tot } 31 \text { januari - } \\
\text { geïnundeerd ( } 100 \% \text { drassig) } \\
\text { Op minimaal } 60 \% \text { van het oppervlak van het perceel is de laag water } \\
\text { tussen de } 5 \text { en } 20 \mathrm{~cm} \text { diep }\end{array}$ \\
\hline Extensief beweid grasland & $6 b$ & $\begin{array}{l}\text { Beweiding is verplicht vanaf } 1 \text { mei tot } 15 \text { oktober met minimaal } 0,15 \\
\text { en maximaal } 0,5 \mathrm{GVE} / \text { ha veebezetting } \\
\text { Rustperiode is van } 1 \text { april tot } 15 \text { oktober } \\
\text { Tijdens de rustperiode wordt de beheereenheid niet gemaaid, gerold, } \\
\text { gesleept, gescheurd, gefreesd, (her)ingezaaid, doorgezaaid of bemest }\end{array}$ \\
\hline Kruidenrijk grasland & $5 a$ & $\begin{array}{l}\text { Er wordt een rustperiode in acht genomen van } 1 \text { april tot } 15 \text { juni } \\
\text { In de rustperiode vinden op de oppervlakte geen bewerkingen plaats } \\
\text { Uitsluitend gebruik van chemische onkruidbestrijding op maximaal } \\
10 \% \text { van de oppervlakte } \\
\text { Het gewas wordt jaarlijks minimaal } 1 \text { keer gemaaid en afgevoerd } \\
\text { Minimaal } 4 \text { verschillende indicatorsoorten zijn in transect aanwezig in } \\
\text { de periode } 1 \text { april tot } 1 \text { oktober } \\
\text { Beweiding is in de rustperiode niet toegestaan } \\
\text { Uitsluitend bemesting met vaste mest toegestaan buiten de } \\
\text { rustperiode } \\
\text { Het gewas wordt jaarlijks voor } 1 \text { augustus afgevoerd door middel van } \\
\text { maaien en afvoeren; een tweede of derde keer maaien en afvoeren is } \\
\text { toegestaan } \\
\text { Het grasland mag niet worden gescheurd, gefreesd of heringezaaid }\end{array}$ \\
\hline Ruige mest & $7 a$ & $\begin{array}{l}\text { Bemesting met ruige stalmest is verplicht } \\
\text { Op de beheereenheid wordt in een kalenderjaar ten minste } 10 \text { en } \\
\text { maximaal } 20 \text { ton ruige stalmest per hectare uitgereden }\end{array}$ \\
\hline Stoppelland & $14 a-d$ & $\begin{array}{l}\text { Er wordt een rustperiode in acht genomen: } \\
\text { van } 1 \text { november en } 15 \text { maart voor winterstoppel van granen } \\
\text { van } 15 \text { oktober tot } 31 \text { december of van } 1 \text { december tot } 1 \text { februari } \\
\text { voor oogstresten van suikerbieten, winterwortel, witlof of pastinaak } \\
\text { die dienen als wintervoedsel } \\
\text { In de rustperiode vinden in de oppervlakte geen bewerkingen plaats } \\
\text { Minimaal } 90 \% \text { tot maximaal } 100 \% \text { van de oppervlakte bestaat in de } \\
\text { rustperiode uit stoppel of gewasresten } \\
\text { Bemesting van de beheereenheid is niet toegestaan tijdens de } \\
\text { rustperiode } \\
\text { Chemische onkruidbestrijding is enkel mogelijk conform het Protocol } \\
\text { Chemische bestrijding bij agrarisch natuurbeheer }\end{array}$ \\
\hline
\end{tabular}




Beheerpakket $\quad$ Beheer Omschrijving
code
juni tot 1 september uit één van de volgende gewassen of teelten: gras, granen (niet zijnde maïs of graanstoppel), ingezaaide kruiden, eiwitgewassen (luzerne, rode klaver), groene braak of een combinatie van deze

De oppervlakte wordt niet beweid

De breedte van de akkerrand kan variëren van 1,5-18 meter Chemische onkruidbestrijding is enkel mogelijk conform het Protocol Chemische bestrijding bij agrarisch natuurbeheer Bemesting van de beheereenheid is niet toegestaan, tenzij het gaat om een rand van tenminste 9 meter breed Er wordt een rustperiode in acht genomen van 15 mei tot 1 maart In de rustperiode vinden in de oppervlakte geen bewerkingen plaats Minimaal $90 \%$ tot maximaal $100 \%$ van de oppervlakte bestaat in de rustperiode uit zomergraan, wintergraan, bladrammenas of een combinatie van deze gewassen Bemesting van de beheereenheid is niet toegestaan tijdens de rustperiode

Chemische onkruidbestrijding is enkel mogelijk conform het Protocol Chemische bestrijding bij agrarisch natuurbeheer Minimaal $90 \%$ en maximaal $100 \%$ van de oppervlakte bestaat tussen 1 juni en 31 december uit één van de volgende gewassen of teelten: granen (niet zijnde maïs of graanstoppel), ingezaaide kruiden, eiwitgewassen (luzerne, rode klaver), groene braak, bladrammenas, gras of een combinatie van deze De oppervlakte wordt niet beweid De eiwitgewassen worden jaarlijks minimaal 1 keer gemaaid en afgevoerd Het graan blijft staan tot 15 maart van het volgende kalender jaar en dient daarna geklepeld of gemaaid en daarna ondergewerkt of afgevoerd te worden in het geval dat er een zomergraan wordt gezaaid

De oppervlakte mag alleen worden bemest op het gedeelte met eiwitgewassen. Als er bemest wordt is alleen rundermest toegestaan Minimaal $90 \%$ tot maximaal $100 \%$ van de oppervlakte bestaat van 1 juni tot 31 december uit één van de volgende gewassen of teelten: granen (niet zijnde mais of graanstoppel), luzerne, bladrammenas, kruiden (ook ingezaaide), eiwitgewassen (klaver- of wikkesoorten) of een combinatie van deze De oppervlakte wordt niet beweid Het overstaande graan, luzerne en bladrammenas worden jaarlijks in het voorjaar (februari of maart) geklepeld om een geschikt zaaibed te krijgen, bij de overblijvende luzerne voor een goede uitstoeling en hergroei, of bij klepelen in de herfst voor de inzaai van wintergraan. De grondbewerking mag niet dieper dan $25 \mathrm{~cm}$ plaatsvinden Chemische onkruidbestrijding is enkel mogelijk conform het Protocol Chemische bestrijding bij agrarisch natuurbeheer Minimaal $40 \%$ tot maximaal $100 \%$ van de oppervlakte bestaat van 15 mei tot 15 juli uit het gewas graan (niet zijnde mais)

Bemesting van de beheereenheid met kunstmest is niet toegestaan In drie tot vijf van de zes jaren van de beheerperiode wordt graan (met uitzondering van mais) verbouwd Chemische onkruidbestrijding is enkel mogelijk conform het Protocol Chemische bestrijding bij agrarisch natuurbeheer 
Wageningen Economic Research Postbus 29703

2502 LS Den Haag

T 0703358330

Ecommunications.ssg@wur.nl

www.wur.nl/economic-research

Wageningen Economic Research RAPPORT

2018-084
De missie van Wageningen University \& Research is 'To explore the potential of nature to improve the quality of life'. Binnen Wageningen University \& Research bundelen Wageningen University en gespecialiseerde onderzoeksinstituten van Stichting Wageningen Research hun krachten om bij te dragen aan de oplossing van belangrijke vragen in het domein van gezonde voeding en leefomgeving. Met ongeveer 30 vestigingen, 5.000 medewerkers en 10.000 studenten behoort Wageningen University \& Research wereldwijd tot de aansprekende kennisinstellingen binnen haar domein. De integrale benadering van de vraagstukken en de samenwerking tussen verschillende disciplines vormen het hart van de unieke Wageningen aanpak. 



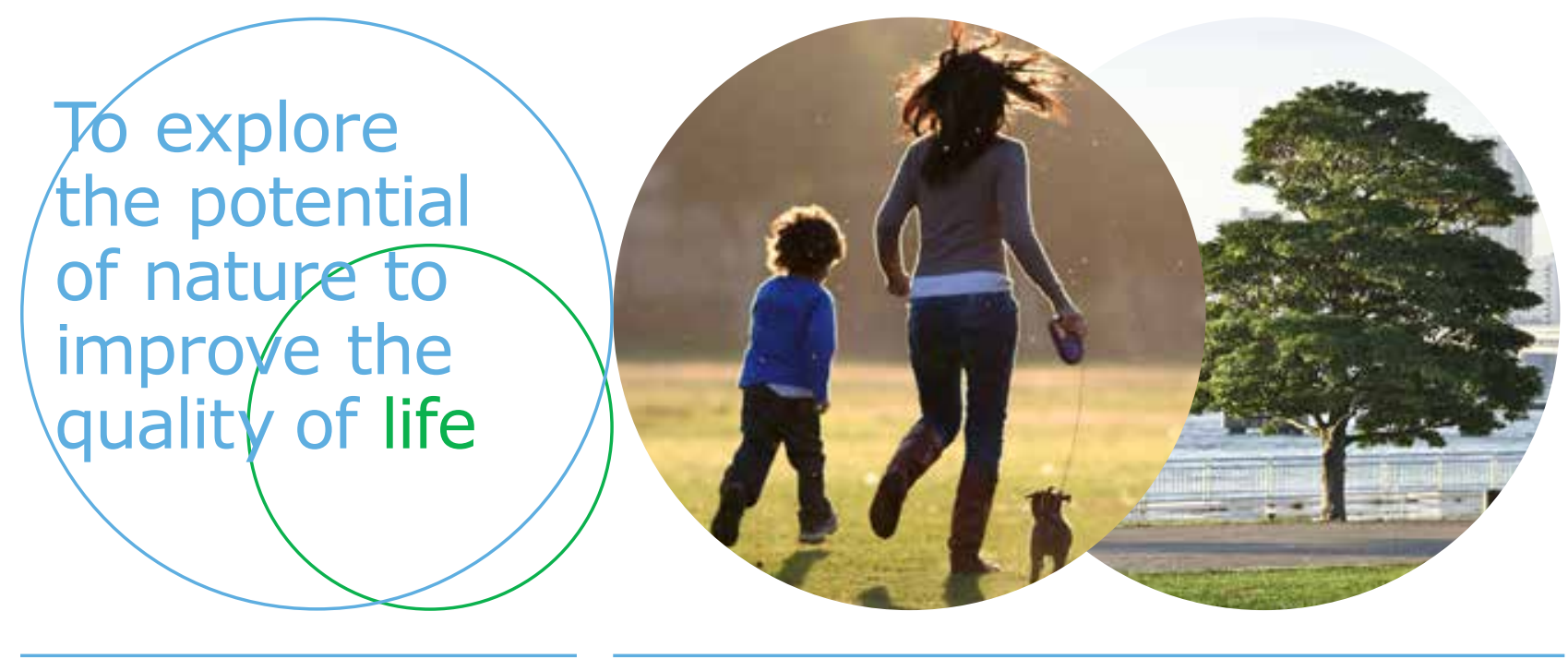

Wageningen Economic Research Postbus 29703

2502 LS Den Haag

E communications.ssg@wur.nl

$\mathrm{T}+31(0) 703358330$

www.wur.nl/economic-research

Report 2018-084

ISBN 978-94-6343-351-8
De missie van Wageningen University \& Research is 'To explore the potential of nature to improve the quality of life'. Binnen Wageningen University \& Research bundelen Wageningen University en gespecialiseerde onderzoeksinstituten van Stichting Wageningen Research hun krachten om bij te dragen aan de oplossing van belangrijke vragen in het domein van gezonde voeding en leefomgeving. Met ongeveer 30 vestigingen, 5.000 medewerkers en 10.000 studenten behoort Wageningen University \& Research wereldwijd tot de aansprekende kennisinstellingen binnen haar domein. De integrale benadering van de vraagstukken en de samenwerking tussen verschillende disciplines vormen het hart van de unieke Wageningen aanpak. 